Bull. Fac. Agric., Cairo Univ., 71:341-356(2020).

\title{
ALLEVIATION OF THE SALINITY EFFECTS ON THE GROWTH AND DEVELOPMENT OF Populus nigra BY EXOGENOUS APPLICATION OF SILICON AND GLYCINE BETAINE
}

(Received: 25.11.2020)

\author{
By \\ Mona A. Amin and E. N. Al-Atrash \\ Timber Trees and Forestry Department, Horticulture Research Institute \\ Agriculture Research Center, Giza, Egypt
}

\begin{abstract}
Populus nigra plants were subjected to four soil salinity levels $\left(0.0,3.0,5.0\right.$ and $\left.7.0 \mathrm{dSm}^{-1}\right)$ in a pot experiment with two types of nutrients foliar applications (silicon at 100 and $200 \mathrm{mg} / \mathrm{l}$ and glycine betaine at 200 and $400 \mathrm{mg} / \mathrm{l})$. Salinity treatments reduced all growth characters. On the other hand, sugars, proline, $\mathrm{Na}$ and $\mathrm{Cl}$ contents increased by increasing salinity levels, while chlorophylls, $\mathrm{N}, \mathrm{P}$ and $\mathrm{K}$ diminished. Foliar application of silicon or glycine betaine enhanced all the studied growth characters, as well as the organic (sugars, proline and chlorophylls) and inorganic components (N,P and $\mathrm{K})$, while $\mathrm{Na}$ and $\mathrm{Cl}$ decreased. The combination of $\mathrm{Si}(200 \mathrm{mg} / \mathrm{l})+\mathrm{GB}(400 \mathrm{mg} / \mathrm{l})$, gave the best results, alleviating the adverse salinity effects on the growth and development of Populus nigra.
\end{abstract}

Key words: Populus nigra, salinity, glycinebetain.

\section{INTRODUCTION}

Black poplar (Populus nigra $\mathrm{L}$ ) is a pioneer deciduous tree species, widely distributed across Europe, Asia and North Africa. It is often used as an ornamental tree, with much desirable wood quality, relatively fire resistant and shock proof, and it has a soft fine texture. Traditionally, it is used for clogs, carts, furniture and flooring near open fireplaces (Zhao et al., 2019), for pulp and paper production, along with fast growth rate, which makes it a suitable bioenergy tree (Zhang et al., 2017). Extracts from the tree have been shown to have antioxidant and anti-inflammatory effects (Yer et al., 2018).

Salinity is a major abiotic stress that affects plant growth and productivity (Parida and Das 2004). Salt stress constitutes an agricultural and environmental problem worldwide, and is expected to cause serious salinization problems for more than $50 \%$ of all arable lands until 2050 (Ehlting et al., 2007). On the other hand, increasing human population, rapid economic growth and the shortage of fresh water have become a fundamental and chronic problem for sustainable agriculture development in arid region (Jiang et al., 2012). So, irrigation with saline water has become inevitable in arid and semi-arid regions (Letey and Feng, 2007) .

Silicon ( $\mathrm{Si}$ ) is the second most prevalent element after oxygen in the soil.
According to more recent definition of the essentiality of elements proposed by Epstein and Bloom (2005), silicon should be considered an essential element for higher plants because silicon-deprived plants tend to grow abnormally , whereas silicon supplemented plants grow normally (Agarie et al., 1992). Regardless of its essentiality in higher plants, $\mathrm{Si}$ has been reported to be beneficial in mitigating both biotic and abotic stresses (Bockhaven et al., 2013 ). Silicon reduces the accumulation of toxic ions by decreasing transpiration due to its deposition as silica in leaves (Matoh et al., 1986). Gong et al. (2006) reported a significant decrease in the uptake of $\mathrm{Na}^{+}$ion in a saline soil due to the deposition of silicon in plant roots. Exogenously applied Si proved to be beneficial for enhancing salt tolerance in plants by adjusting the levels of compatible solutes such as increasing soluble sugars and increasing proline content in the salt stressed and decreasing the synthesis of phenolic compounds (Hashemi et al., 2010).

Glycine Betaine (GB) is a quaternary amine plays a highly beneficial role in plants exposed to various stress conditions such as high level of salts and low temperature. Many plant species naturally accumulate GB and proline as major organic osmolytes when subjected to different abiotic stress, where these compounds are 
thought to play adaptive roles in mediating osmotic adjustment and protecting subcellular structures in stressed plants. However, not all plants accumulate GB or proline in sufficient amounts to help averting adverse effects. Thus, an exogenous application of these osmolytes to plants growing under stress conditions may enhance their tolerance to abiotic stress (Kanu et al., 2017). Exogenous foliar application of GB has been suggested as an approach to induce stress tolerance in crops with poor or no solute accumulating ability (Ashraf and Foolad, 2007).

The aim of this investigation is to alleviate the salinity harmful effects on the growth and development of Populus nigra seedlings by exogenous application of silicon and glycine betaine

\section{MATERIALS AND METHODS}

The work was carried out at the experimental area of Timber Trees and Forestry Dep., Hort. Res. Inst., A.R.C. Giza, Egypt, during two successive seasons of 2018/2019 and $2019 / 2020$ to study the effects of salinity, silicon and glycine betaine on Populus nigra seedlings grown under sandy loamy soil conditions. Seedlings (one year old) with an average height of $25-30 \mathrm{~cm}$, stem diameter at base of $0.3 \mathrm{~cm}$, were used. The seedlings were obtained from the nursery of Forestry Department, Horticultural Research Institute. The seedlings were transplanted individually in plastic pots of (30 $\mathrm{cm}$ height and $25 \mathrm{~cm}$ diameter),filled with 12 $\mathrm{kg}$ mixture of sand and clay ( $2: 1, \mathrm{v}: \mathrm{v})$.

The chemical and physical analysis of the used soil mixture are shown in Table (1) Chemical analysis of the soil samples was performed according to the method of Black, (1982). Seedlings were planted on February $1^{\text {st }}$ in both seasons (2018/2019 and 2019/2020). The soil mixture was subjected to three salinity levels (3.0, 5.0 and $\left.7.0 \mathrm{dsm}^{-1}\right)$ which were obtained by adding a mixture of (sodium chloride, calcium chloride and magnesium sulphate at the ratio of $2: 2: 1$ by weight, respectively, besides the control (tap water).

\subsection{Preparation of the salt solution}

A stock solution with concentration of (100 $\mathrm{dSm}^{-1}$ ) was prepared as follows:

$25.6 \mathrm{~g}$ of $\mathrm{NaCl}, 25.6 \mathrm{~g}$ of $\mathrm{CaCl}_{2}$ and $12.8 \mathrm{~g}$ of $\mathrm{MgSO}_{4}$ were dissolved in one liter of tap water to prepare the solution. The following volumes were used to prepare the solutions in the next Table:

\begin{tabular}{|c|c|c|}
\hline $\begin{array}{c}\text { Concentration } \\
\left(\mathbf{d S} \mathbf{~ m}^{-\mathbf{1}}\right)\end{array}$ & $\begin{array}{c}\text { Volume } \\
\text { from } \\
\text { stock(ml) }\end{array}$ & $\begin{array}{c}\text { Final } \\
\text { volume } \\
(\mathbf{m l})\end{array}$ \\
\hline $\left.3(\mathrm{dS} \mathrm{m})^{-1}\right)$ & $30 \mathrm{ml}$ & $1000 \mathrm{ml}$ \\
\hline $5\left(\mathrm{dS} \mathrm{m}^{-1}\right)$ & $50 \mathrm{ml}$ & $1000 \mathrm{ml}$ \\
\hline $7\left(\mathrm{dS} \mathrm{m}^{-1}\right)$ & $70 \mathrm{ml}$ & $1000 \mathrm{ml}$ \\
\hline
\end{tabular}

Three salt concentrations $\left(3,5\right.$ and $\left.7 \mathrm{dSm}^{-1}\right)$ whereas:

$\left(1 \mathrm{dS} \mathrm{m}^{-1}\right)=640 \mathrm{ppm}$, as well as the control (Tap water).

Foliar application of two substances were used in this experiment (silicon and glycine betaine) individually, and as a mixture (Sigma Chemicals, USA), with three concentrations levels of $(0.0,100$ and $200 \mathrm{mg} / \mathrm{l})$ calcium silicate $\left(\mathrm{CaO}_{4} \mathrm{Si}\right)$, and $(0.0,200$ and $400 \mathrm{mg} / \mathrm{l})$ of Glycine betaine (trimethly glycine $\left(\mathrm{C}_{5} \mathrm{H}_{11} \mathrm{NO}_{2}\right)$.

For each salinity level, the pots were divided to nine groups according to foliar application of Si and GB treatments.

Foliar applications were sprayed twice per month starting after 30 days from transplanting and the saline solution (the volume of water added to plants was $3.4501 /$ pot according to $100 \%$ field capacity determined in used soil) was used three time weekly in the summer and twice a week in the winter, and the pots leached with tap water up to field capacity once each month to avoid salt accumulation in root zone.

Hence, the experiment included three levels of salinity as well as control in which the plants irrigated with tap water (control) and nine levels

Table(1) : Physical and chemical analysis of the used soil.

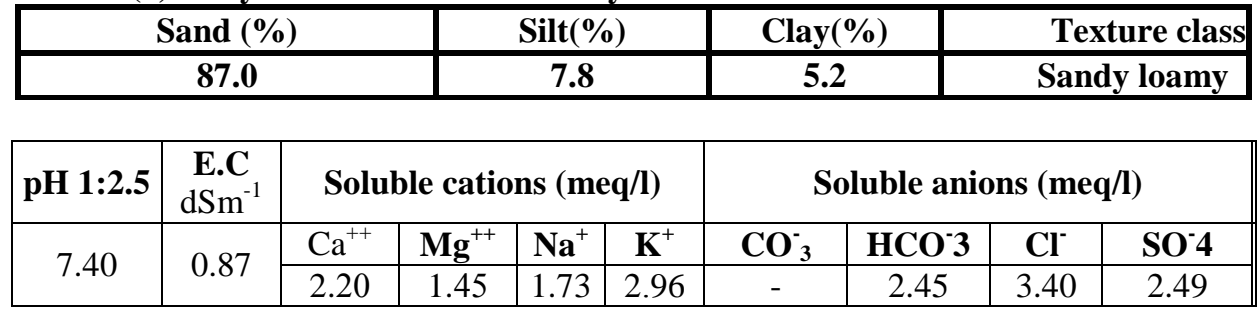


of foliar application of $\mathrm{Si}$ and $\mathrm{GB}$, making 36 treaments with three replicates for each treatment as follows:

1- Tap water(control)

2-Spraying with $100 \mathrm{mg} / \mathrm{l} \mathrm{Si}\left(\mathrm{Si}_{1}\right)$

3- Spraying with $200 \mathrm{mg} / \mathrm{l} \mathrm{Si}\left(\mathrm{Si}_{2}\right)$

4- Spraying with $200 \mathrm{mg} / \mathrm{l} \mathrm{GB}\left(\mathrm{GB}_{1}\right)$

5- Spraying with $400 \mathrm{mg} / \mathrm{l} \mathrm{GB}\left(\mathrm{GB}_{2}\right)$

6- Spraying with $100 \mathrm{mg} / \mathrm{l} \mathrm{Si}+200 \mathrm{mg} / \mathrm{l} \mathrm{GB}$ $\left(\mathrm{Si}_{1+} \mathrm{GB}_{1}\right)$

7- Spraying with $100 \mathrm{mg} / \mathrm{lSi}+.400 \mathrm{~m} \mathrm{~g} / \mathrm{l} \mathrm{GB}$ $\left(\mathrm{Si}_{1+} \mathrm{GB}_{2}\right)$

8- Spraying with $200 \mathrm{mg} / \mathrm{l} \mathrm{Si}+200 \mathrm{mg} / \mathrm{l} \mathrm{GB}$ $\left(\mathrm{Si}_{2}+\mathrm{GB}_{1}\right)$

9- Spraying with200mg / $\mathrm{Si}+400 \mathrm{mg} / \mathrm{l} \mathrm{GB}$ $\left(\mathrm{Si}_{2+} \mathrm{GB}_{2}\right)$

The following data were recorded at the end of September of both seasons.

- Seedling height $(\mathrm{cm})$

-Root length $(\mathrm{cm})$

- Stem diameter $(\mathrm{cm})$.

-Number of leaves /seedling

-Fresh and dry weights of shoots and roots (g/ seedling).

\subsection{Chemical analysis}

- Total chlorophylls (mg/g fresh weight of leaves) were extracted with dimethyl formamide solution according to Mornai (1982).

- Total sugars were determined in shoots using the phenol sulphuric acid reagent as the method described by Dubois et al. (1956)

- Free proline concentration in shoots was measured colorimetrically using ninhydrin reagent according to Bates et al. (1973).

Nutritional elements determination:

The wet digestion of $0.5 \mathrm{~g}$ of dry plant material (shoots) with sulphuric and perchloric acid was used as described by Piper (1947).

a) Nitrogen concentration was detrmined by Nessler method according to the Official Methods of Analysis A.O.A.C. (1990).

b) Phosphorus concentration was estimated colorimetrically using the chlorostannous reduced molybdophosphoric blue colour method as described by King (1951).

c) Sodium and potassium concentrations were determined using the flame photometer apparatus CORNINGM410 as described by
Chapman and Pratt (1961).

e) Chloride concentration was detrmined by titration method with silver nitrate according to Brown and Jackson (1955).

\subsection{Statistical analysis}

The layout of the experiment was split plot design, as the main plots were salinity levels and subplots were the foliar applications of $\mathrm{Si}$ and GB ,so the experiment included 36 treatments, each treatment had three replicates. The obtained data were statistically analyzed according to Duncan multiple range test 5\% (1955) and Snederor and Cochran (1980).

\section{RESULTS AND DISCUSSIONS}

3.1. Alleviation of salinity effects on the growth parameters of Populus nigra seedlings by exogenous application of silicon and glycine betaine

\subsubsection{Seedling height}

Data presented in Table (2) indicated that increasing salinity levels significantly decreased seedling height in descending order (98.90, 91.37 and $86.39 \mathrm{~cm}$ ) with the treatments $3.0,5.0$ and $7.0 \mathrm{dSm}^{-1}$,respectively, in the first season compared to the control $(132.4 \mathrm{~cm})$.

Regarding foliar application of Si and GB, the data illustrated that all treatments significantly increased the seedling height as compared to control, moreover increasing the concentration of both $\mathrm{Si}$ and/or GB significantly increased seedling height except for the treatment of $\mathrm{Si}_{1+} \mathrm{GB}_{1}$ and $\mathrm{Si}_{2+} \mathrm{GB}_{1}$.

The interaction between salinity level of irrigation water and foliar application of $\mathrm{Si}$ and/or GB, showed that in the first season, plants irrigated with the lowest level of salinity (3 $\mathrm{dSm}{ }^{-1}$ ) and sprayed with $\mathrm{Si}_{2+} \mathrm{GB}_{2}$ resulted in the tallest seedlings $(125.0 \mathrm{~cm})$, whereas control recorded $(120.0 \mathrm{~cm})$, and this increased seedling height by $4.2 \%$, whereas shortest seedlings were recorded in the plants irrigated with high level of salinity $\left(7 \mathrm{dSm}^{-1}\right)$ without exogenous application $(72.0 \mathrm{~cm})$, but the highest value under the same salinity level was found with $\mathrm{Si}_{2}+\mathrm{GB}_{2}$ treatment $(96.67 \mathrm{~cm})$. Similar results were obtained in the second season. 
Table (2): Alleviation of salinity effects on seedling height (cm)of Populus nigra seedlings by exogenous application of silicon and glycine betaine during 2018/2019 and 2019/2020.

\begin{tabular}{|c|c|c|c|c|c|c|c|c|c|c|}
\hline Charactere & \multicolumn{10}{|c|}{$\begin{array}{l}\text { Seedlings height }(\mathrm{cm}) \\
\text { Salinity levels }\left(\mathrm{dSm}^{-1}\right) \\
\end{array}$} \\
\hline Salinity levels & Control & $3 \mathrm{dSm}^{-1}$ & $5 \mathrm{dSm}^{-1}$ & $7 \mathrm{dSm}^{-1}$ & $* * *$ Mean & Control & $3 \mathrm{dSm}^{-1}$ & $5 \mathrm{dSm}^{-1}$ & $7 \mathrm{dSm}^{-1}$ & $* * *$ Mean \\
\hline Treatments & \multicolumn{5}{|c|}{ First season 2018/2019 } & \multicolumn{5}{|c|}{ Second season 2019/2020 } \\
\hline Control & $120.7 \mathrm{e}$ & $88.00 \mathrm{no}$ & $79.67 \mathrm{~s}$ & $72.00 t *$ & $90.09 \mathrm{H}$ & $125.0 \mathrm{j}$ & $101.7 \mathrm{~m}$ & $87.33 p$ & $66.00 \mathrm{u} *$ & $95.01 \mathrm{H}$ \\
\hline $\mathbf{S i}_{1}$ & 123.0de & $89.00 \mathrm{~m}-\mathrm{o}$ & $83.00 \mathrm{qr}$ & $80.67 \mathrm{rs}$ & $93.92 \mathrm{G}$ & $128.3 \mathrm{i}$ & $115.3 \mathrm{k}$ & $92.33 \mathrm{o}$ & $69.33 \mathrm{t}$ & $101.32 \mathrm{G}$ \\
\hline $\mathbf{S i}_{2}$ & $125.30 \mathrm{~d}$ & $91.67 \mathrm{j}-1$ & $85.00 \mathrm{pq}$ & $82.33 \mathrm{r}$ & $96.08 \mathrm{~F}$ & $135.7 \mathrm{f}$ & $123.7 \mathrm{j}$ & $95.33 n$ & $73.00 \mathrm{~s}$ & $106.93 \mathrm{~F}$ \\
\hline $\mathbf{G B}_{1}$ & $132.3 \mathrm{c}$ & 94.00ij & $90.67 \mathrm{k}-\mathrm{m}$ & $85.33 \mathrm{pq}$ & $100.58 \mathrm{E}$ & $143.7 \mathrm{e}$ & $130.70 \mathrm{hi}$ & 111.71 & $76.00 \mathrm{r}$ & $115.53 \mathrm{D}$ \\
\hline $\mathbf{G B}_{2}$ & $133.3 \mathrm{c}$ & $96.00 \mathrm{hi}$ & $92.33 \mathrm{j}-1$ & $87.00 \mathrm{op}$ & $102.16 \mathrm{D}$ & $147.0 \mathrm{~d}$ & $136.7 \mathrm{f}$ & $117.7 \mathrm{k}$ & $53.67 \mathrm{v}$ & $113.77 \mathrm{E}$ \\
\hline $\mathbf{S i}_{1+} \mathbf{G B}_{1}$ & $137.3 b$ & $100.70 \mathrm{~g}$ & 96.0hi & $90.171-n$ & $106.04 \mathrm{C}$ & $150.7 \mathrm{c}$ & $143.3 \mathrm{e}$ & $124.0 \mathrm{j}$ & $82.33 q$ & $125.08 \mathrm{C}$ \\
\hline $\mathbf{S i}_{1+} \mathbf{G B}{ }_{2}$ & $140.7 \mathrm{a}$ & $103.7 \mathrm{f}$ & $97.33 \mathrm{~h}$ & $93.00 \mathrm{jk}$ & $108.68 \mathrm{~B}$ & $155.0 \mathrm{~b}$ & $146.7 \mathrm{~d}$ & $132.7 \mathrm{gh}$ & $86.67 \mathrm{p}$ & $130.27 \mathrm{~B}$ \\
\hline $\mathbf{S i}_{2+} \mathbf{G B}_{1}$ & $137.0 \mathrm{~b}$ & $102.0 \mathrm{fg}$ & 95.67hi & $90.331-n$ & $106.25 \mathrm{C}$ & $152.0 \mathrm{c}$ & $141.0 \mathrm{e}$ & $123.3 \mathrm{j}$ & $80.67 q$ & $124.25 \mathrm{C}$ \\
\hline $\mathbf{S i}_{2+} \mathbf{G B}_{2}$ & $142.3 \mathrm{a}$ & $125.0 \mathrm{~d}$ & $102.7 \mathrm{fg}$ & $96.67 \mathrm{~h}$ & $116.67 \mathrm{~A}$ & $162.0 \mathrm{a}$ & $150.3 \mathrm{c}$ & $134.7 \mathrm{fg}$ & $90.67 \mathrm{o}$ & $134.42 \mathrm{~A}$ \\
\hline ***Mean & $132.4 \mathrm{~A}$ & $98.90 \mathrm{~B}$ & $91.37 \mathrm{C}$ & $86.39 \mathrm{D}$ & & $144.38 \mathrm{~A}$ & $132.16 \mathrm{~B}$ & $113.23 \mathrm{C}$ & 75.37D & \\
\hline
\end{tabular}

$\mathrm{Si}_{1}(\mathrm{Silicon} 100 \mathrm{mg} / \mathrm{l}), \mathrm{S}_{2}(\mathrm{Silicon} 200 \mathrm{mg} / \mathrm{l}), \mathrm{GB}_{1}(\mathrm{Glycinbetian} 200 \mathrm{mg} / \mathrm{l}), \mathrm{GB}_{2}(\mathrm{Glycinbetian} 400 \mathrm{mg} / \mathrm{l})$

***Means values in the same column within each spraying substances followed by the same capital letters are not significant al level $5 \%$ probability.

**Means values in the same row within each irrigated with different levels of salinity followed by same capital letters are not significant at level of $5 \%$.

*Mean values in the same row or column within the interaction followed by the same small letter are not significant at $5 \%$.

\subsubsection{Stem diameter}

As shown in Table (3) the data indicated that increased salinization levels significantly decreased stem diameter in a descending order $(1.29,1.18$ and $1.04 \mathrm{~cm})$ with the treatments of 3.0,5.0 and $7.0 \mathrm{dSm}^{-1}$, the respectively in the first season compared to control $(1.36 \mathrm{~cm})$.

Regarding foliar application of $\mathrm{Si}$ and GB the data illustrated that all treatments significantly increased stem diameter as compared to control (neither salinized nor sprayed plants). On the other hand, increasing concentration of both $\mathrm{Si}$ and/or GB significantly increased stem diameter..

Also, the data about the interaction between salinity level and foliar application of $\mathrm{Si}$ and/or GB, in the first season showed that, the plants irrigated with the lowest level of salinity $\left(3 \mathrm{dSm}^{-1}\right)$ and sprayed with $\mathrm{Si}_{2}+\mathrm{GB}{ }_{2}$ recorded the thickest stem diameter $(1.74 \mathrm{~cm})$ compared to control (neither salinized nor sprayed) which recorded $(0.95 \mathrm{~cm})$ giving $83 \%$ increment, whereas the lowest value of stem diameter exhibited in the plants irrigated with high level of salinity $\left(7 \mathrm{dSm}^{-1}\right)$ without any exogenous application of Si or GB $(0.74 \mathrm{~cm})$ but the highest value under the same salinity level was recorded with $\mathrm{Si}_{2}+\mathrm{GB}_{2}(1.30 \mathrm{~cm})$. Similar results were obtained in the second season except with $\mathrm{Si}_{1}+$ $\mathrm{GB}_{2}$ and $\mathrm{Si}_{2}+\mathrm{GB}_{1}$ which showed no significant difference.

\subsubsection{Root length}

Data in Table (4) indicated that increasing salinization levels significantly decreased root length giving $55.22,52.19$ and $47.78 \mathrm{~cm}$ with the treatments of $3.0,5.0$ and $7.0 \mathrm{dSm}^{-1}$ salinity level respectively in the first season compared to control (non salinized $59.59 \mathrm{~cm}$ ). The foliar application of Si and GB treatments significantly increased the root length as compared to control (neither salinized nor sprayed). On the other hand, increasing the concentration of both $\mathrm{Si}$ and/or GB significantly increased root length.

Concerning the interaction effects, it was found that the plants irrigated with salinity at 3 $\mathrm{dSm}^{-1}$ and sprayed with $\mathrm{Si}_{2}+\mathrm{GB}_{2}$ recorded the longest roots $(66.67 \mathrm{~cm})$ compared to the control $(46.0 \mathrm{~cm})$ and this increased root length by $45 \%$, whereas shortest roots, exhibited in the plants irrigated with salinity at $7 \mathrm{dSm}^{-1}$ and did not receive any exogenous application of $\mathrm{Si}$ or GB $(35.0 \mathrm{~cm})$ but the longest roots under the same salinity level were obtained with $\mathrm{Si}_{2}+\mathrm{GB}_{2}$ $(57.0 \mathrm{~cm})$. Similar results were obtained in the second season, except for the treatments of $\mathrm{Si}_{1}$ ${ }_{+} \mathrm{GB}_{1}$ and $\mathrm{Si}_{2+} \mathrm{GB}_{1}$. 
Table (3): Alleviation of salinity effects on Stem diameter (cm) of Populus nigra seedlings by exogenous application of silicon and glycine betaine during 2018/2019 and2019/2020.

\begin{tabular}{|c|c|c|c|c|c|c|c|c|c|c|}
\hline Charactere & \multicolumn{10}{|c|}{$\begin{array}{c}\text { Stem diameter }(\mathrm{cm}) \\
\text { Salinity levels }\left(\mathrm{dSm}^{-1}\right) \\
\end{array}$} \\
\hline Salinity levels & Control & $3 \mathrm{dSm}^{-1}$ & $5 \mathrm{dSm}^{-}$ & $7 \mathrm{dSm}^{-1}$ & $* * *$ Mean & Control & $3 \mathrm{dSm}^{-1}$ & $5 \mathrm{dSm}$ & $17 \mathrm{dSm}^{-1}$ & $* * *$ Mean \\
\hline Treatments & \multicolumn{5}{|c|}{ First season 2018/2019 } & \multicolumn{5}{|c|}{ Second season 2019/2020 } \\
\hline Control & $0.95 q$ & $0.86 \mathrm{~s}$ & $0.81 \mathrm{t}$ & $0.74 \mathrm{v}^{*}$ & $0.84 \mathrm{I}$ & $1.22 q$ & $0.91 \mathrm{~s}$ & $0.81 \mathrm{t}$ & $0.66 \mathrm{v} *$ & $0.90 \mathrm{H}$ \\
\hline $\mathbf{S i}_{1}$ & $1.12 \mathrm{o}$ & $1.09 \mathrm{p}$ & $0.91 \mathrm{r}$ & $0.79 \mathrm{u}$ & $0.98 \mathrm{H}$ & $1.25 \mathrm{o}$ & $1.21 \mathrm{p}$ & $0.83 \mathrm{r}$ & $0.69 \mathrm{u}$ & $1.00 \mathrm{G}$ \\
\hline $\mathrm{Si}_{2}$ & $1.18 \mathrm{n}$ & $1.14 \mathrm{o}$ & $0.97 \mathrm{q}$ & $0.81 \mathrm{t}$ & $1.02 \mathrm{G}$ & $1.29 \mathrm{n}$ & $1.23 \mathrm{o}$ & $0.86 q$ & $0.72 \mathrm{t}$ & $1.03 \mathrm{~F}$ \\
\hline GB $_{1}$ & $1.27 \mathrm{j}$ & $1.20 \mathrm{~m}$ & $1.12 \mathrm{o}$ & $0.95 q$ & $1.14 \mathrm{~F}$ & $1.31 \mathrm{j}$ & $1.261 \mathrm{~m}$ & $0.91 \mathrm{o}$ & $0.75 \mathrm{q}$ & $1.06 \mathrm{E}$ \\
\hline $\mathbf{G B}_{2}$ & $1.44 \mathrm{f}$ & $1.25 \mathrm{k}$ & $1.25 \mathrm{k}$ & $1.17 \mathrm{n}$ & $1.28 \mathrm{E}$ & $1.34 \mathrm{f}$ & $1.30 \mathrm{k}$ & $0.94 \mathrm{k}$ & $0.79 n$ & 1.09D \\
\hline $\mathrm{Si}_{1+} \mathbf{G B}_{1}$ & $1.45 \mathrm{ef}$ & $1.45 \mathrm{ef}$ & $1.31 \mathrm{i}$ & $1.19 \mathrm{~m}$ & $1.35 \mathrm{C}$ & $1.37 \mathrm{f}$ & $1.32 \mathrm{f}$ & $1.33 \mathrm{i}$ & $0.82 \mathrm{~m}$ & $1.21 \mathrm{~B}$ \\
\hline $\mathrm{Si}_{1+} \mathbf{G B}_{2}$ & $1.48 \mathrm{~d}$ & $1.46 \mathrm{e}$ & $1.34 \mathrm{~h}$ & $1.23 \mathrm{k}$ & $1.38 \mathrm{~B}$ & $1.43 \mathrm{~d}$ & $1.37 \mathrm{e}$ & $1.09 \mathrm{f}$ & $0.87 \mathrm{k}$ & $1.19 \mathrm{BC}$ \\
\hline $\mathbf{S i}_{2+} \mathbf{G B}_{1}$ & $1.45 \mathrm{ef}$ & $1.40 \mathrm{~g}$ & $1.30 \mathrm{i}$ & 1.211 & $1.34 \mathrm{D}$ & $1.38 \mathrm{ef}$ & $1.34 \mathrm{~g}$ & $1.09 \mathrm{i}$ & 0.881 & $1.17 \mathrm{C}$ \\
\hline $\mathbf{S i}_{2+} \mathbf{G B}_{2}$ & $1.91 \mathrm{a}$ & $1.74 \mathrm{~b}$ & $1.59 \mathrm{c}$ & $1.30 \mathrm{i}$ & $1.63 \mathrm{~A}$ & $1.64 \mathrm{a}$ & $1.43 \mathrm{~b}$ & $1.22 \mathrm{c}$ & $0.93 \mathrm{i}$ & $1.30 \mathrm{~A}$ \\
\hline **Mean & $1.36 \mathrm{~A}$ & $1.29 \mathrm{~B}$ & $1.18 \mathrm{C}$ & 1.04D & & $1.36 \mathrm{~A}$ & $1.26 \mathrm{~B}$ & $1.01 \mathrm{C}$ & $0.79 \mathrm{D}$ & \\
\hline
\end{tabular}

$\mathrm{Si}_{1}$ (Silicon100mg/l), $\mathrm{S}_{2}$ (Silicon200mg/l), $\mathrm{GB}_{1}($ Glycinbetian 200mg/l), GB 2 (Glycinbetian 400mg/l).

values in the same column within each spraying substances followed by the same capital letters are not significant al level $5 \%$ probability.

**Means values in the same row within each irrigated with different levels of salinity followed by same capital letters are not significant at level of $5 \%$.

*Mean values in the same row orcolumn within the interaction followed by the same small

Table (4): Alleviation of salinity effects on Root length (cm) of Populus nigra seedlings by exogenous application of silicon and glycine betaine during 2018/2019 and2019/2020.

\begin{tabular}{|c|c|c|c|c|c|c|c|c|c|c|}
\hline Charactere & \multicolumn{10}{|c|}{$\begin{array}{c}\text { Root length }(\mathrm{cm}) \\
\text { Salinity levels }\left(\mathrm{dSm}^{-1}\right) \\
\end{array}$} \\
\hline Salinity levels & Control & $3 \mathrm{dSm}^{-1}$ & $5 \mathrm{dSm}^{-1}$ & $7 \mathrm{dSm}^{-1}$ & $* * *$ Mean & Control & $3 \mathrm{dSm}^{-1}$ & $5 \mathrm{dSm}^{-1}$ & $7 \mathbf{d S m}^{-1}$ & $* * *$ Mean \\
\hline Treatments & \multicolumn{5}{|c|}{ First season 2018/2019 } & \multicolumn{5}{|c|}{ Second season 2019/2020 } \\
\hline Control & $46.00 \mathrm{qr}$ & $43.00 \mathrm{st}$ & $40.00 \mathrm{u}$ & $35.00 \mathrm{v} *$ & $41.00 \mathrm{I}$ & $60.33 \mathrm{~g}$ & $44.00 \mathrm{mn}$ & $35.00 \mathrm{op}$ & $27.67 q^{*}$ & $41.75 \mathrm{H}$ \\
\hline $\mathbf{S i}_{1}$ & $51.001-n$ & $46.00 \mathrm{qr}$ & $45.33 \mathrm{qr}$ & $41.67 \mathrm{tu}$ & $46.00 \mathrm{H}$ & $65.33 \mathrm{f}$ & $47.33 \mathrm{kl}$ & $42.00 \mathrm{n}$ & $34.00 \mathrm{p}$ & $47.17 \mathrm{G}$ \\
\hline $\mathbf{S i}_{2}$ & 53.00i-1 & $50.33 \mathrm{~m}-\mathrm{o}$ & $46.67 \mathrm{q}$ & 44.00rs & $48.50 \mathrm{G}$ & $67.00 \mathrm{~d}-\mathrm{f}$ & $51.00 \mathrm{ij}$ & $44.33 \mathrm{mn}$ & $37.00 \mathrm{o}$ & $49.83 \mathrm{~F}$ \\
\hline $\mathbf{G B}_{1}$ & $55.67 \mathrm{f}-\mathrm{h}$ & $52.00 \mathrm{j}-\mathrm{m}$ & 48.67op & $47.33 \mathrm{pq}$ & $50.92 \mathrm{~F}$ & $69.00 \mathrm{de}$ & $55.33 \mathrm{~h}$ & $47.67 \mathrm{kl}$ & $42.3 n$ & $53.58 \mathrm{E}$ \\
\hline $\mathbf{G B}_{2}$ & $60.33 \mathrm{e}$ & $55.00 \mathrm{~g}-\mathrm{i}$ & $53.33 \mathrm{i}-\mathrm{k}$ & $50.33 \mathrm{~m}-\mathrm{o}$ & $54.5 \mathrm{E}$ & $73.00 \mathrm{c}$ & $60.33 \mathrm{~g}$ & $52.33 \mathrm{i}$ & $45.331 \mathrm{~m}$ & $57.75 \mathrm{D}$ \\
\hline $\mathrm{Si}_{1+} \mathbf{G B}_{1}$ & $66.00 \mathrm{bc}$ & $60.33 \mathrm{e}$ & 56.00f-h & $51.33 \mathrm{k}-\mathrm{n}$ & $58.42 \mathrm{C}$ & $75.33 b c$ & $65.67 \mathrm{f}$ & $56.00 \mathrm{~h}$ & $49.33 \mathrm{jk}$ & $61.58 \mathrm{C}$ \\
\hline $\mathrm{Si}_{1+} \mathbf{G B}_{2}$ & $67.67 \mathrm{~b}$ & $66.33 \mathrm{bc}$ & $59.67 \mathrm{e}$ & $54.00 \mathrm{~h}-\mathrm{j}$ & $61.92 \mathrm{~B}$ & $75.67 \mathrm{~b}$ & 69.00de & $60.00 \mathrm{~g}$ & $56.67 \mathrm{~h}$ & $65.34 \mathrm{~B}$ \\
\hline $\mathbf{S i}_{2+} \mathbf{G B}_{1}$ & $65.00 \mathrm{~cd}$ & $57.33 \mathrm{f}$ & $56.00 f-h$ & 49.33no & $56.92 \mathrm{D}$ & $75.33 \mathrm{bc}$ & 66.67ef & $56.33 \mathrm{~h}$ & $47.00 \mathrm{kl}$ & $61.33 \mathrm{C}$ \\
\hline $\mathrm{Si}_{2+} \mathbf{G B}_{2}$ & $71.67 \mathrm{a}$ & $66.67 \mathrm{bc}$ & $64.00 \mathrm{~d}$ & $57.00 \mathrm{fg}$ & $64.84 \mathrm{~A}$ & $85.67 \mathrm{a}$ & $77.00 \mathrm{~b}$ & $69.33 \mathrm{~d}$ & $60.33 \mathrm{~g}$ & $73.08 \mathrm{~A}$ \\
\hline **Mean & $59.59 \mathrm{~A}$ & $55.22 \mathrm{~B}$ & $52.19 \mathrm{C}$ & $47.78 \mathrm{D}$ & & $71.85 \mathrm{~A}$ & $59.59 \mathrm{~B}$ & $51.44 \mathrm{C}$ & 44.41D & \\
\hline
\end{tabular}

$\mathrm{Si}_{1}\left(\right.$ Silicon100mg/l), $\mathrm{S}_{2}$ (Silicon200mg/l), GB 1 (Glycinbetian 200mg/l), GB 2 (Glycinbetian 400mg/l)

***Means values in the same column within each spraying substances followed by the same capital letters are not significant al level $5 \%$ probability.

**Means values in the same row within each irrigated with different levels of salinity followed by same capital letters are not significant at level of $5 \%$.

* Mean values in the same row or column within the interaction followed by the same small letter are not significant at $5 \%$. 


\subsubsection{Number of leaves/seedling}

Data presented in Table (5) indicated that there were significant decreases in the number of leaves in a descending order (58.70, 49.30 and sprayed with $\mathrm{Si}_{2}+\mathrm{GB}_{2} \quad$ (55.67leaves/plant). Similar results obtained in the second season except withSi $i_{1}+\mathrm{GB}_{1}$ and $\mathrm{Si}_{2}+\mathrm{GB}_{1}$ which showed no significant differences.

Table (5): Alleviation of salinity effects on numberof leaves/plant of Populus nigra seedlings by exogenous application of silicon and glycine betaine during 2018/2019 and2019/2020.

\begin{tabular}{|c|c|c|c|c|c|c|c|c|c|c|}
\hline Charactere & \multicolumn{10}{|c|}{$\begin{array}{c}\text { No. of leaves/plant } \\
\text { Salinity levels }\left(\mathrm{dSm}^{-1}\right)\end{array}$} \\
\hline Salinity levels & Control & $3 \mathrm{dSm}^{-1}$ & $5 \mathrm{dSm}^{-1}$ & $7 \mathrm{dSm}^{-1}$ & $* * *$ Mean & Control & $3 \mathrm{dSm}^{-1}$ & $5 \mathrm{dSm}^{-1}$ & $7 \mathrm{dSm}^{-1}$ & $* * *$ Mean \\
\hline Treatments & \multicolumn{5}{|c|}{ First season 2018/2019 } & \multicolumn{5}{|c|}{ Second season 2019/2020 } \\
\hline Control & 35.330 & $25.33 \mathrm{r}$ & $22.00 \mathrm{~s}$ & $16.00 \mathrm{t}$ & $24.67 \mathrm{I}$ & $50.33 \mathrm{kl}$ & 34.330 & $27.00 \mathrm{pq}$ & $20.67 \mathrm{r}$ & $33.08 \mathrm{H}$ \\
\hline $\mathbf{S i}_{1}$ & $38.67 \mathrm{n}$ & $32.33 \mathrm{pq}$ & $60.67 q$ & $20.33 \mathrm{~s}$ & $30.50 \mathrm{H}$ & 55.33hi & $42.33 \mathrm{~m}$ & $33.67 \mathrm{o}$ & $24.67 \mathrm{q}$ & $39.00 \mathrm{G}$ \\
\hline $\mathbf{S i}_{2}$ & $44.00 \mathrm{~m}$ & $40.00 \mathrm{n}$ & $34.00 \mathrm{op}$ & $21.67 \mathrm{~s}$ & $34.92 \mathrm{G}$ & $60.33 \mathrm{~g}$ & 48.001 & $38.00 \mathrm{n}$ & $29.00 \mathrm{p}$ & $43.83 \mathrm{~F}$ \\
\hline GB $_{1}$ & $75.33 \mathrm{f}$ & 52.671 & $43.67 \mathrm{~m}$ & $24.67 \mathrm{r}$ & $49.09 \mathrm{~F}$ & $65.00 \mathrm{f}$ & $57.00 \mathrm{hi}$ & $44.00 \mathrm{~m}$ & $33.00 \mathrm{o}$ & $49.75 \mathrm{E}$ \\
\hline $\mathbf{G B}_{2}$ & $82.00 \mathrm{e}$ & $62.00 \mathrm{ij}$ & $56.67 \mathrm{k}$ & $27.00 \mathrm{r}$ & $56.92 \mathrm{E}$ & $69.00 \mathrm{~d}$ & $62.00 \mathrm{~g}$ & $48.67 \mathrm{kl}$ & $38.67 \mathrm{n}$ & $54.59 \mathrm{D}$ \\
\hline $\mathbf{S i}_{1+} \mathbf{G B}_{1}$ & $76.67 d$ & $66.33 \mathrm{~h}$ & $60.00 \mathrm{j}$ & $31.67 \mathrm{pq}$ & 61.17D & $72.67 \mathrm{c}$ & 67.00d-f & $51.33 \mathrm{~h}$ & $43.00 \mathrm{~m}$ & $58.50 \mathrm{C}$ \\
\hline $\mathrm{Si}_{1+} \mathbf{G B}_{2}$ & $92.00 \mathrm{~b}$ & $82.67 \mathrm{e}$ & $64.33 \mathrm{hi}$ & $43.67 \mathrm{~m}$ & 70.67B & $80.33 b$ & $73.00 \mathrm{c}$ & $57.33 \mathrm{~h}$ & 47.671 & $64.58 \mathrm{~B}$ \\
\hline $\mathbf{S i}_{2+} \mathbf{G B}_{1}$ & $87.33 \mathrm{~cd}$ & $77.33 \mathrm{f}$ & $60.00 \mathrm{j}$ & $40.67 n$ & $66.33 \mathrm{C}$ & $75.00 \mathrm{c}$ & $65.67 \mathrm{ef}$ & $55.00 \mathrm{hi}$ & $44.00 \mathrm{~m}$ & $59.92 \mathrm{C}$ \\
\hline $\mathrm{Si}_{2+} \mathbf{G B}_{2}$ & $95.00 \mathrm{a}$ & $89.67 \mathrm{bc}$ & $72.33 \mathrm{~g}$ & $55.67 \mathrm{k}$ & $78.17 \mathrm{~A}$ & $87.00 \mathrm{a}$ & $78.33 \mathrm{~b}$ & $67.67 \mathrm{de}$ & $54.00 \mathrm{ij}$ & $72.00 \mathrm{~A}$ \\
\hline **Mean & $70.70 \mathrm{~A}$ & $58.70 \mathrm{~B}$ & $49.30 \mathrm{C}$ & $31.26 \mathrm{D}$ & & $68.33 \mathrm{~A}$ & $58.63 \mathrm{~B}$ & $47.07 \mathrm{C}$ & 37.19D & \\
\hline
\end{tabular}

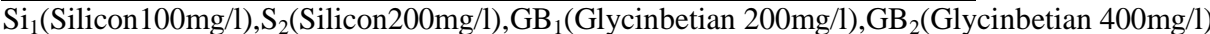

***Means values in the same column within each spraying substances followed by the same capital letters are not significant al level $5 \%$ probability.

**Means values in the same row within each irrigated with different levels of salinity followed by same capital letters are not significant at level of $5 \%$.

*Mean values in the same row orcolumn within the interaction followed by the same small letter are not significant at $5 \%$.

31.26 leaves/plant) with the treatments of 3.0,5.0 and $7.0 \mathrm{dSm}^{-1}$ salinity level, respectively, in the first season compared to the control (70.70 leaves/plant).

Regarding foliar application of $\mathrm{Si}$ and GB data illustrated that all treatments significantly increased the number of leaves as compared to control (non salinized). On the other hand, increasing concentration of both $\mathrm{Si}$ and/or GB significantly increased the number of leaves.

Regarding the interaction effect between salinity level and foliar application of $\mathrm{Si}$ and/or GB, the obtained data showed that the plants irrigated with the lowest level of salinity $\left(3 \mathrm{dSm}^{-1}\right)$ and sprayed with $\mathrm{Si}_{2}+\mathrm{GB}_{2}$ formed the highest the number of leaves $(89.67$ leaves/plant) compared to control (35.33 leaves/plant) and this increased number of leaves by $154 \%$, whereas the least number of leaves was exhibited in the plants irrigated with high level of salinity $\left(7 \mathrm{dSm}^{-1}\right)$ and did not receive any exogenous application of $\mathrm{Si}$ or $\mathrm{GB}$ (16.00 leaves/plant), but the highest value under the same salinity level was recorded in plants

\subsubsection{Fresh and dry weights of shoots}

Data presented in Tables (6 and 7) indicated that increased salinization levels significantly decreased fresh and dry weights of shoots in descending order giving (141.2,131.1 and 111.6 $\mathrm{g} /$ plant) and (49.50, 43.28 and $35.91 \mathrm{~g} / \mathrm{plant})$ with the treatments of $\left(3.0,5.0\right.$ and $7.0 \mathrm{dSm}^{-1}$ salinity level ),respectively, in the first season compared to the control non salinized 149.1 and $53.13 \mathrm{~g} /$ plant, respectively.

Regarding foliar application of Si and GB, it was found that all treatments significantly increased fresh and dry weights of shoots as compared to control (neither salinized nor sprayed). On the other hand, increasing concentration of both $\mathrm{Si}$ and/or GB significantly increased fresh and dry weights of shoots except with $\mathrm{Si}_{1}+\mathrm{GB}_{1}, \mathrm{Si}_{2}+\mathrm{GB}_{1}$ and $\mathrm{Si}_{1}+\mathrm{GB}_{2}$ which showed no significant differences in the dry weight.

As for the interaction, the data showed that the plants irrigated with the lowest level of salinity $\left(3 \mathrm{dSm}^{-1}\right)$ and sprayed with $\mathrm{Si}_{2}+\mathrm{GB}{ }_{2}$ recorded the highest value of fresh and dry 
Table (6): Alleviation of salinity effects on fresh weights of shoots (g/plant)of Populus nigra seedlings by exogenous application of silicon and glycine betaine during 2018/2019 and2019/2020.

\begin{tabular}{|c|c|c|c|c|c|c|c|c|c|c|}
\hline \multirow{2}{*}{$\begin{array}{c}\text { Charactere } \\
\text { Salinity levels }\end{array}$} & \multirow{2}{*}{\begin{tabular}{|l|} 
Control \\
\end{tabular}} & \multicolumn{9}{|c|}{$\begin{array}{c}\text { Fresh weights of shoots (g/plant) } \\
\text { Salinity levels }\left(\mathrm{dSm}^{-1}\right)\end{array}$} \\
\hline & & $3 \mathbf{d S m}^{-1}$ & $5 \mathrm{dSm}^{-1}$ & $7 \mathrm{dSm}^{-1}$ & ****Mean & Control & $3 \mathrm{dSm}^{-1}$ & $5 \mathrm{dSm}^{-1}$ & $7 \mathrm{dSm}^{-1}$ & $* * *$ Mean \\
\hline Treatments & & \multicolumn{4}{|c|}{ First season 2018/2019 } & \multicolumn{5}{|c|}{ Second season 2019/2020 } \\
\hline Control & $126.7 \mathrm{kl}$ & $118.3 \mathrm{no}$ & $92.67 q$ & $82.00 \mathrm{~s}^{*}$ & $104.9 \mathrm{I}$ & $141.0 \mathrm{kl}$ & $125.7 \mathrm{o}$ & $118.0 \mathrm{p}$ & $71.33 \mathrm{v}^{*}$ & $114.0 \mathrm{I}$ \\
\hline $\mathbf{S i}_{1}$ & $131.3 \mathrm{j}$ & $121.7 \mathrm{mn}$ & $115.0 \mathrm{op}$ & $86.67 \mathrm{r}$ & $113.7 \mathrm{H}$ & $145.7 \mathrm{j}$ & $135.0 \mathrm{mn}$ & \begin{tabular}{l|l}
$\mathrm{n}$ & $126.7 \mathrm{o}$
\end{tabular} & $76.00 \mathrm{u}$ & $120.9 \mathrm{H}$ \\
\hline $\mathbf{S i}_{2}$ & $134.0 \mathrm{ij}$ & $131.7 \mathrm{j}$ & $121.7 \mathrm{mn}$ & $92.33 q$ & $119.9 \mathrm{G}$ & $150.7 \mathrm{hi}$ & $140.3 \mathrm{kl}$ & $132.0 \mathrm{n}$ & $82.67 \mathrm{t}$ & $126.4 \mathrm{G}$ \\
\hline $\mathbf{G B}_{1}$ & $143.7 \mathrm{~g}$ & 137.0hi & 133.0ij & $111.0 \mathrm{p}$ & $131.2 \mathrm{~F}$ & $158.0 \mathrm{fg}$ & $43.3 \mathrm{jk}$ & $138.01 \mathrm{~m}$ & $85.33 \mathrm{st}$ & $131.2 \mathrm{~F}$ \\
\hline $\mathbf{G B}_{2}$ & $151.3 \mathrm{de}$ & $141.7 \mathrm{~g}$ & 137.0hi & $120.0 \mathrm{mn}$ & $\begin{array}{ll}n & 137.5 \mathrm{E} \\
\end{array}$ & $162.7 \mathrm{de}$ & $147.3 \mathrm{ij}$ & $141.3 \mathrm{kl}$ & $89.00 \mathrm{~s}$ & $135.1 \mathrm{E}$ \\
\hline $\mathbf{S i}_{1+} \mathbf{G B}_{1}$ & $156.0 \mathrm{c}$ & $148.7 \mathrm{ef}$ & 141.0gh & $124.01 \mathrm{~m}$ & $142.4 \mathrm{D}$ & $168.0 \mathrm{c}$ & $151.7 \mathrm{~h}$ & $146.0 \mathrm{j}$ & $94.00 \mathrm{r}$ & 139.9D \\
\hline $\mathrm{Si}_{1+} \mathbf{G B}_{2}$ & $165.0 \mathrm{~b}$ & $155.0 \mathrm{~cd}$ & $145.3 \mathrm{fg}$ & $130.3 \mathrm{jk}$ & 148.9B & $172.0 \mathrm{~b}$ & 161.3ef & $150.7 \mathrm{hi}$ & $96.67 \mathrm{r}$ & $145.2 \mathrm{~B}$ \\
\hline $\mathbf{S i}_{2+} \mathbf{G B}_{1}$ & $162.3 \mathrm{~b}$ & $151.7 \mathrm{c}-\mathrm{e}$ & $142.0 \mathrm{~g}$ & 126.01 & $145.5 \mathrm{C}$ & $166.7 \mathrm{c}$ & $157.0 \mathrm{~g}$ & 150.3hi & $94.67 \mathrm{r}$ & $142.2 \mathrm{C}$ \\
\hline $\mathbf{S i}_{2+} \mathbf{G B}_{2}$ & $171.3 \mathrm{a}$ & $165.0 \mathrm{~b}$ & $152.0 \mathrm{c}-\mathrm{e}$ & $132.3 \mathrm{j}$ & $155.2 \mathrm{~A}$ & $182.7 \mathrm{a}$ & $166.0 \mathrm{~cd}$ & $158.3 \mathrm{fg}$ & $111.0 \mathrm{q}$ & $154.5 \mathrm{~A}$ \\
\hline$* *$ Mean & $149.1 \mathrm{~A}$ & $141.2 \mathrm{~B}$ & $131.1 \mathrm{C}$ & $111.6 \mathrm{D}$ & & $160.8 \mathrm{~A}$ & 147.5B & $140.1 \mathrm{C}$ & $88.96 \mathrm{D}$ & \\
\hline
\end{tabular}

$\mathrm{Si}_{1}($ Silicon $100 \mathrm{mg} / \mathrm{l}), \mathrm{S}_{2}\left(\right.$ Silicon200mg/l), GB ${ }_{1}($ Glycinbetian $200 \mathrm{mg} / \mathrm{l}), \mathrm{GB}_{2}($ Glycinbetian $400 \mathrm{mg} / \mathrm{l})$

$* * *$ Means values in the same column within each spraying substances followed by the same capital letters are not significant al level $5 \%$ probability.

**Means values in the same row within each irrigated with different levels of salinity followed by same capital letters are not significant at level of $5 \%$.

*Mean values in the same row orcolumn within the interaction followed by the same small letter are not significant at 5\%.

Table (7): Alleviation of salinity effects on dry weights of shoots (g/plant)of Populus nigra seedlings by exogenous application of silicon and glycine betaine. during 2018/2019 and2019/2020.

\begin{tabular}{|c|c|c|c|c|c|c|c|c|c|c|}
\hline \multirow{3}{*}{$\begin{array}{c}\text { Charactere } \\
\text { Salinity levels } \\
\text { Treatments }\end{array}$} & & \multicolumn{9}{|c|}{$\begin{array}{c}\text { Dry weights of shoots (g/plant) } \\
\text { Salinity levels }\left(\mathrm{dSm}^{-1}\right)\end{array}$} \\
\hline & \multirow[t]{2}{*}{ Control } & $3 \mathrm{dSm}^{-1}$ & & & & & $\mathrm{ISm}^{-1}$ & $5 \mathrm{dSm}^{-1}$ & $7 \mathrm{dSm}^{-1}$ & \\
\hline & & \multicolumn{4}{|c|}{ First season 2018/2019 } & \multicolumn{5}{|c|}{ Second season 2019/2020 } \\
\hline Control & $46.33 \mathrm{f}-\mathrm{h}$ & $42.53 \mathrm{j}-1$ & 31.930 & $27.00 p^{*}$ & $36.95 \mathrm{I}$ & $43.60 \mathrm{kl}$ & $38.07 \mathrm{o}$ & \begin{tabular}{l|l}
$35.60 p$ \\
\end{tabular} & $20.79 \mathrm{v}^{*}$ & $34.52 \mathrm{H}$ \\
\hline $\mathbf{S i}_{1}$ & & $44.57 \mathrm{~g}-\mathrm{j}$ & $35.63 n$ & & & $48.53 \mathrm{e}-\mathrm{h}$ & $41.201-\mathrm{r}$ & $9.07 \mathrm{no}$ & & $8 \mathrm{G}$ \\
\hline $\mathbf{S i}_{2}$ & $48.17 \mathrm{f}$ & $46.57 \mathrm{f}-\mathrm{h}$ & $40.201 \mathrm{~m}$ & 27.9 & 40.72 & $46.27 \mathrm{~h}-\mathrm{j}$ & $43.43 \mathrm{kl}$ & \begin{tabular}{l|l}
1 & $40.73 \mathrm{mn}$ \\
\end{tabular} & $24.17 \mathrm{tu}$ & $38.65 \mathrm{G}$ \\
\hline $\mathbf{G B}_{1}$ & $51.53 \mathrm{de}$ & $47.23 \mathrm{fg}$ & $43.57 \mathrm{i}-\mathrm{k}$ & 31.6 & 43.5 & $48.67 \mathrm{e}-\mathrm{h}$ & $45.23 \mathrm{jk}$ & \begin{tabular}{l|l}
$\mathrm{k}$ & $42.271 \mathrm{~m}$
\end{tabular} & $25.67 \mathrm{st}$ & $46 \mathrm{~F}$ \\
\hline & $7 \mathrm{~cd}$ & $47.23 \mathrm{fg}$ & $45.63 \mathrm{f}-\mathrm{i}$ & 38.4 & 46.2 & & 46.7 & $-\mathrm{j} 4$ & & \\
\hline $\mathrm{Si}_{1+} \mathbf{G B} \mathbf{B}_{1}$ & 55.6 & $51.89 \mathrm{de}$ & $46.70 \mathrm{fg}$ & $41.30 \mathrm{kl}$ & $48.89 \mathrm{CD}$ & $52.30 \mathrm{bc}$ & $47.83 \mathrm{f}-1$ & \begin{tabular}{l|l}
$\mathrm{i}$ & $45.80 \mathrm{i}-\mathrm{k}$ \\
\end{tabular} & $28.37 \mathrm{gr}$ & $43.58 \mathrm{D}$ \\
\hline $\mathrm{Si}_{1+} \mathbf{G B}_{2}$ & $89 \mathrm{~b}$ & $55.64 \mathrm{bc}$ & $48.00 \mathrm{f}$ & $42.07 \mathrm{j}-1$ & 50.90B & $53.71 \mathrm{ab}$ & $50.33 c-c$ & \begin{tabular}{l|l|l} 
e & $47.00 \mathrm{~h}-\mathrm{j}$ \\
\end{tabular} & $29.21 q$ & $45.06 \mathrm{BC}$ \\
\hline & $5.87 \mathrm{~b}$ & $53.87 \mathrm{~cd}$ & $47.00 \mathrm{fg}$ & $42.57 \mathrm{j}-1$ & $50.08 \mathrm{BC}$ & $51.90 \mathrm{~b}-\mathrm{d}$ & $49.67 \mathrm{~d}-\mathrm{z}$ & \begin{tabular}{l|l|l|}
$\mathrm{g}$ & $47.53 \mathrm{~g}-\mathrm{j}$ \\
\end{tabular} & $27.73 q-\mathrm{s}$ & $44.21 \mathrm{CD}$ \\
\hline $\mathrm{Si}_{2+} \mathbf{G B}_{2}$ & & $56.01 \mathrm{bc}$ & $50.90 \mathrm{e}$ & $43.93 \mathrm{~h}-\mathrm{k}$ & & & $51.50 \mathrm{~b}-\mathrm{c}$ & \begin{tabular}{l|l}
$\mathrm{d}$ & $50.03 \mathrm{c}-\mathrm{f}$
\end{tabular} & $33.63 p$ & $47.60 \mathrm{~A}$ \\
\hline$* *$ Mean & $53.13 \mathrm{~A}$ & $49.50 \mathrm{~B}$ & $43.28 \mathrm{C}$ & 35.91D & & $50.08 \mathrm{~A}$ & $46.00 \mathrm{~B}$ & $43.50 \mathrm{C}$ & $26.47 \mathrm{D}$ & \\
\hline
\end{tabular}

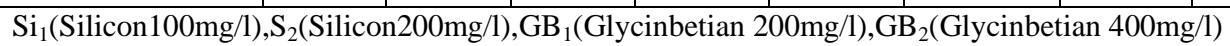

***Means values in the same column within each spraying substances followed by the same capital letters are not significant al level $5 \%$ probability.

**Means values in the same row within each irrigated with different levels of salinity followed by same capital letters are not significant at level of $5 \%$.

*Mean values in the same row orcolumn within the interaction followed by the same small letter are not significant at $5 \%$. 
weights of shoots (165.0 and $56.01 \mathrm{~g} / \mathrm{plant})$ compared to the control (126.7 and 46.33 g/plant), which increased the fresh and dry weights of shoots by $30 \%$ and $21 \%$, respectively, whereas the lowest value was obtained in the plants irrigated with high level of salinity $\left(7 \mathrm{dSm}^{-1}\right)$ without exogenous application of $\mathrm{Si}$ and $\mathrm{GB}$ (82.0 and $27.0 \mathrm{~g} / \mathrm{plant}$ ) but the highest values under the same salinity level was recorded in plants sprayed with $\mathrm{Si}_{2}+\mathrm{GB}_{2}$ (132.3 and 43. $93 \mathrm{~g} / \mathrm{plant})$. Similar results were obtained in the second season.

\subsubsection{Fresh and dry weights of roots}

Data presented in Tables (8 and 9) indicated that increased salinity levels in irrigation water significantly decreased fresh and dry weights of roots in descending order (57.07,51.70 and 48.26 $\mathrm{g} / \mathrm{plant}$ ) and (16.31, 14.88 and $11.75 \mathrm{~g} / \mathrm{plant})$ with the treatments of $\left(3.0,5.0\right.$ and $\left.7.0 \mathrm{dSm}^{-1 /}\right)$ compared to the control ( 62.29 and $17.40 \mathrm{~g}$ /plant).

With regard to the effect of Si and GB, the data illustrated that all treatments significantly increased fresh and dry weights of roots as compared to control (neither salinized nor sprayed). On the other hand, increasing concentration of both $\mathrm{Si}$ and/or GB significantly increased fresh and dry weights of roots except with $\mathrm{Si}_{1}+\mathrm{GB}_{1}$ and $\mathrm{Si}_{2}+\mathrm{GB}_{1}$, which showed no significant difference .
The interaction showed that the plants irrigated with the lowest level of salinity $(3 \mathrm{~d}$ $\mathrm{Sm}^{-1}$ ) and sprayed with $\mathrm{Si}_{2}+\mathrm{GB}{ }_{2}$ recorded the highest value of fresh and dry weights of roots (70.33 and $20.43 \mathrm{~g} / \mathrm{plant}$ ) compared to the control (46.33 and $12.47 \mathrm{~g} /$ plant) which increased $52 \%$ and $39 \%$ over the control, respectively. Whereas, the lowest value of fresh and dry weights of roots exhibited in the plants irrigated with high level of salinity $\left(7 \mathrm{dSm}^{-1}\right)$ and did not receive any exogenous application (28.67 and $5.63 \mathrm{~g} / \mathrm{plant}$ ) but the highest value under the same salinity level was obtained with $\mathrm{Si}_{2}+\mathrm{GB}_{2}$ (61.00 and $16.27 \mathrm{~g} /$ plant). Similar results were obtained in the second season .

Finally, the obtained results showed that salinity deteriorated all growth parameters of Populus nigra seedlings and this deterioration increased with increasing the salinity level of irrigation. This inhibitory effect of salinity may be due to a number of physiological processes such as a decrease in meristematic activity and/ or cell enlargement (Sakr et al., 2007) and also may be attributed to high osmotic pressure of soil solution which restricted the absorption of water by plant root and /or to the toxic effects of certain ions present in soil solution (Nour ElDin et al., 1984).

Table (8): Alleviation of salinity effects on Fresh weights of roots(g/plant)of Populus nigra seedlings by exogenous application of silicon and glycine betaine. during 2018/2019 and2019/2020.

\begin{tabular}{|c|c|c|c|c|c|c|c|c|c|c|}
\hline \multirow{3}{*}{$\begin{array}{c}\text { Charactere } \\
\text { Salinity levels } \\
\text { Treatments }\end{array}$} & \multicolumn{10}{|c|}{$\begin{array}{c}\text { Fresh weights of roots }(\mathrm{g} / \mathrm{plant}) \\
\text { Salinity levels }\left(\mathrm{dSm}^{-1}\right)\end{array}$} \\
\hline & Control & $3 \mathrm{dSm}^{-1}$ & $5 \mathrm{dSm}^{-1}$ & $7 \mathrm{dSm}^{-1}$ & $* * *$ Mean & Control & $3 \mathrm{dSm}^{-1}$ & $5 \mathrm{dSm}^{-1}$ & $7 \mathrm{dSm}^{-1}$ & ****Mean \\
\hline & & \multicolumn{4}{|c|}{ First season $2018 / 2019$} & \multicolumn{5}{|c|}{ Second season 2019/2020 } \\
\hline Control & 46.331 & $40.33 \mathrm{~m}$ & $33.00 \mathrm{n}$ & $28.67 \mathrm{O}^{*}$ & $37.08 \mathrm{H}$ & $62.00 \mathrm{kl}$ & $49.33 q$ & $40.33 \mathrm{st}$ & $25.33 \mathrm{w}^{*}$ & $44.25 \mathrm{H}$ \\
\hline $\mathbf{S i}_{1}$ & $51.67 \mathrm{k}$ & 46.671 & $41.00 \mathrm{~m}$ & $34.00 \mathrm{n}$ & $43.34 \mathrm{G}$ & $65.33 \mathrm{~h}-\mathrm{j}$ & $52.671 \mathrm{~m}$ & $46.00 \mathrm{r}$ & $29.33 \mathrm{v}$ & $48.33 \mathrm{G}$ \\
\hline $\mathbf{S i}_{2}$ & $55.33 \mathrm{ij}$ & $50.33 \mathrm{k}$ & $43.00 \mathrm{~m}$ & $40.33 \mathrm{~m}$ & $47.25 \mathrm{~F}$ & $67.33 \mathrm{gh}$ & $57.00 \mathrm{n}$ & $51.33 \mathrm{pq}$ & 32.00uv & $51.92 \mathrm{~F}$ \\
\hline $\mathbf{G B}_{1}$ & $60.33 \mathrm{~cd}$ & $55.33 \mathrm{ij}$ & $50.33 \mathrm{k}$ & $43.67 \mathrm{~m}$ & $52.42 \mathrm{E}$ & $72.33 \mathrm{e}$ & $60.671 \mathrm{~m}$ & $55.33 \mathrm{no}$ & $34.00 \mathrm{u}$ & $55.58 \mathrm{E}$ \\
\hline $\mathbf{G B}_{2}$ & 63.00ef & $60.33 \mathrm{f}-\mathrm{h}$ & $55.33 \mathrm{ij}$ & $52.00 \mathrm{jk}$ & 57.67D & $77.33 \mathrm{e}$ & $64.00 \mathrm{i}-\mathrm{k}$ & $\mathrm{k} 58.33 \mathrm{mn}$ & $38.00 \mathrm{t}$ & $59.42 \mathrm{D}$ \\
\hline $\mathbf{S i}_{1+} \mathbf{G B}_{1}$ & $67.33 \mathrm{~cd}$ & $63.00 \mathrm{ef}$ & $59.33 \mathrm{f}-\mathrm{h}$ & $57.67 \mathrm{~g}-\mathrm{i}$ & $61.83 \mathrm{C}$ & $81.33 \mathrm{c}$ & $66.67 \mathrm{~g}-\mathrm{i}$ & i $61.33 \mathrm{kl}$ & $41.00 \mathrm{~s}$ & $62.58 \mathrm{C}$ \\
\hline $\mathbf{S i}_{1+} \mathbf{G B}_{2}$ & $71.33 \mathrm{~b}$ & $65.33 \mathrm{de}$ & $61.67 f$ & $59.67 \mathrm{f}-\mathrm{h}$ & $64.50 \mathrm{~B}$ & $86.00 \mathrm{~b}$ & 71.67ef & f $69.00 \mathrm{fg}$ & $44.67 \mathrm{r}$ & $67.84 \mathrm{~B}$ \\
\hline $\mathbf{S i}_{2+} \mathbf{G B}_{1}$ & $69.00 \mathrm{bc}$ & $62.00 \mathrm{ef}$ & $59.67 \mathrm{f}-\mathrm{h}$ & 57.33hi & $62.00 \mathrm{C}$ & $79.00 \mathrm{~cd}$ & 71.00ef & $63.33 \mathrm{j}-1$ & $41.67 \mathrm{~s}$ & $63.75 \mathrm{C}$ \\
\hline $\mathrm{Si}_{2+} \mathbf{G B}_{2}$ & 76.33a & $70.33 b c$ & 62.00ef & 61.00fg & $67.42 \mathrm{~A}$ & $92.67 \mathrm{a}$ & $80.67 \mathrm{c}$ & 71.33ef & $57.33 n$ & $75.50 \mathrm{~A}$ \\
\hline **Mean & $62.29 \mathrm{~A}$ & $57.07 \mathrm{~B}$ & $51.70 \mathrm{C}$ & 48.26D & & $75.92 \mathrm{~A}$ & 63.74B & $57.34 \mathrm{C}$ & 38.15D & \\
\hline
\end{tabular}

$\mathrm{Si}_{1}\left(\right.$ Silicon100mg/l), $\mathrm{S}_{2}$ (Silicon200mg/l),GB ${ }_{1}$ (Glycinbetian 200mg/l),GB ${ }_{2}($ Glycinbetian 400mg/l)

***Means values in the same column within each spraying substances followed by the same capital letters are not significant al level $5 \%$ probability.

**Means values in the same row within each irrigated with different levels of salinity followed by same capital letters are not significant at level of $5 \%$.

*Mean values in the same row orcolumn within the interaction followed by the same small letter are not significant at $5 \%$. 
Table (9): Alleviation of salinity effects on dry weights of roots(g/plant)of Populus nigra seedlings by exogenous application of silicon and glycine betaine during 2018/2019 and2019/2020.

\begin{tabular}{|c|c|c|c|c|c|c|c|c|c|c|}
\hline \multirow{4}{*}{\begin{tabular}{|c|} 
Charactere \\
Salinity levels \\
Treatments \\
Control \\
\end{tabular}} & \multicolumn{10}{|c|}{$\begin{array}{l}\text { Dry weights of roots }(\mathrm{g} / \mathrm{plant}) \\
\text { Salinity levels }\left(\mathrm{dSm}^{-1}\right)\end{array}$} \\
\hline & \multirow{2}{*}{ Control } & $3 \mathrm{dSm}^{-1}$ & $5 \mathrm{dSm}^{-1}$ & $7 \mathrm{dSm}^{-1} \mid *$ & ****Mean & Control & $3 \mathrm{dSm}^{-1}$ & $5 \mathrm{dSm}^{-1}$ & $7 \mathrm{dSm}^{-1}$ & ****Mean \\
\hline & & \multicolumn{4}{|c|}{ First season 2018/2019 } & \multicolumn{5}{|c|}{\begin{tabular}{|l|} 
Second season $2019 / 2020$ \\
\end{tabular}} \\
\hline & $12.47 \mathrm{k}-\mathrm{m}$ & $10.47 \mathrm{no}$ & $8.33 \mathrm{p}$ & $5.63 \mathrm{q}^{*}$ & $9.23 \mathrm{H}$ & $16.67 \mathrm{i}-1$ & $14.10 \mathrm{no}$ & $9.47 \mathrm{~s}$ & $4.90 \mathrm{v}^{*}$ & $11.29 \mathrm{H}$ \\
\hline $\mathbf{S i}_{1}$ & $13.89 \mathrm{i}-1$ & $12.78 \mathrm{j}-\mathrm{m}$ & $11.67 \mathrm{mn}$ & $8.08 p$ & $11.61 \mathrm{G}$ & $17.72 \mathrm{i}-\mathrm{k}$ & $15.87 \mathrm{~lm}$ & $11.29 \mathrm{qr}$ & $6.11 \mathrm{u}$ & $12.75 \mathrm{G}$ \\
\hline $\mathbf{S i}_{2}$ & $15.43 \mathrm{f}-\mathrm{i}$ & $14.08 \mathrm{~h}-\mathrm{k}$ & $12.331 \mathrm{~m}$ & $9.17 \mathrm{op}$ & $12.75 \mathrm{~F}$ & $19.21 \mathrm{~h}$ & $16.63 \mathrm{j}-1$ & $13.10 \mathrm{op}$ & $7.43 \mathrm{t}$ & $14.09 \mathrm{~F}$ \\
\hline GB $_{1}$ & $17.10 \mathrm{~d}-\mathrm{f}$ & $15.78 \mathrm{f}-\mathrm{h}$ & $14.08 \mathrm{~h}-\mathrm{k}$ & 10.63 no & $14.40 \mathrm{E}$ & $21.47 \mathrm{ef}$ & $17.93 \mathrm{ij}$ & $13.50 \mathrm{o}$ & $7.93 \mathrm{t}$ & $15.21 \mathrm{E}$ \\
\hline $\mathbf{G B}_{2}$ & $18.23 \mathrm{~cd}$ & $17.77 \mathrm{c}-\mathrm{e}$ & $15.73 \mathrm{f}-\mathrm{h}$ & $12.60 \mathrm{k}-\mathrm{m}$ & \begin{tabular}{ll|}
$\mathrm{n}$ & $16.08 \mathrm{D}$ \\
\end{tabular} & 22.65de & $18.01 \mathrm{i}$ & $15.20 \mathrm{mn}$ & $9.67 \mathrm{~s}$ & $16.38 \mathrm{D}$ \\
\hline $\mathrm{Si}_{1+} \mathbf{G B}_{1}$ & $18.21 \mathrm{~cd}$ & $18.33 \mathrm{~cd}$ & $16.87 \mathrm{~d}-\mathrm{f}$ & $14.17 \mathrm{~h}-\mathrm{k}$ & \begin{tabular}{|l|l|}
$\mathrm{k}$ & $16.90 \mathrm{C}$ \\
\end{tabular} & $24.03 c$ & $19.73 \mathrm{gh}$ & $16.44 \mathrm{k}-\mathrm{m}$ & \begin{tabular}{|l|}
$10.87 \mathrm{r}$ \\
\end{tabular} & $17.77 \mathrm{C}$ \\
\hline $\mathrm{Si}_{1+} \mathbf{G B}_{2}$ & $20.33 b$ & $19.11 \mathrm{bc}$ & $18.19 \mathrm{~cd}$ & $14.87 \mathrm{~g}-\mathrm{i}$ & \begin{tabular}{|l|l|}
$\mathrm{i}$ & $18.13 \mathrm{~B}$ \\
\end{tabular} & $25.60 \mathrm{~b}$ & $20.87 \mathrm{fg}$ & $17.23 \mathrm{i}-\mathrm{k}$ & $12.23 \mathrm{pq}$ & $18.98 \mathrm{~B}$ \\
\hline $\mathbf{S i}_{2+} \mathbf{G B}_{1}$ & $18.10 \mathrm{~cd}$ & $18.00 \mathrm{~cd}$ & $17.57 \mathrm{c}-\mathrm{e}$ & $14.37 \mathrm{~h}-\mathrm{j}$ & $\begin{array}{l}\mathrm{j} \\
\mathrm{j}\end{array}$ & $23.63 \mathrm{~cd}$ & $20.55 \mathrm{fg}$ & $17.20 \mathrm{i}-\mathrm{k}$ & $11.60 \mathrm{qr}$ & $18.25 \mathrm{C}$ \\
\hline $\mathrm{Si}_{2+} \mathbf{G B}_{2}$ & $22.87 \mathrm{a}$ & $20.43 b$ & $19.13 b c$ & $16.27 \mathrm{e}-\mathrm{g}$ & $\mathrm{g} 19.68 \mathrm{~A}$ & $28.23 \mathrm{a}$ & $23.58 \mathrm{~cd}$ & $20.04 \mathrm{gh}$ & $15.431 \mathrm{~m}$ & $21.82 \mathrm{~A}$ \\
\hline **Mean & $17.40 \mathrm{~A}$ & 16.31B & $14.88 \mathrm{C}$ & $11.75 \mathrm{D}$ & & $22.13 \mathrm{~A}$ & $18.59 \mathrm{~B}$ & $14.83 \mathrm{C}$ & $9.57 \mathrm{D}$ & \\
\hline
\end{tabular}

Also, the results revealed that exogenous foliar application of $\mathrm{Si}$ and/or GB could alleviate the harmful effects of salinity on all growth parameters of the plant, which may be due to that, Si have been associated with an increase in antioxidant defense abilities and enhanced plant tolerance to abiotic stress (Liang et al., 2006 and Gong et al ., 2005). Exogenous application of GB to plants before, during or after stress exposure have been shown to enhance plant growth and final crop yield under stress conditions (Kanu et al., 2017). The exact mechanism of the effect of these osmoregulators may be due to osmotic protection (Arteca, 1996) or promotion of the uptake of essential macronutrients which then facilitated normal growth and development (Foyer and Spencer 1986).

\subsection{Alleviation of salinity effects on chemical composition of Populus nigra seedlings by exogenous application of silicon and glycine betaine}

\subsubsection{Total chlorophylls}

Data presented in Table (10) indicated that increased salinization levels significantly decreased total chlorophylls in a descending order $(0.75,0.71$ and $0.64 \mathrm{mg} / \mathrm{g}$ F.W.), the treatments were $\left(3.0,5.0\right.$ and $7.0 \mathrm{dSm}^{-1}$ salinity levels), respectively, compared to the control $(0.80 \mathrm{mg} / \mathrm{g} \mathrm{F} . \mathrm{W})$.
Regarding foliar application of Si and GB, the obtained data indicated that all treatments significantly increased total chlorophylls as compared to control, but increasing concentration of both Si and/or GB significantly increased it. Also, the data of the interaction between salinity level and foliar application of $\mathrm{Si}$ and/or GB showed that the plants irrigated with the lowest level of salinity $\left(3 \mathrm{dSm}^{-1}\right)$ and sprayed with $\mathrm{Si}_{2}+\mathrm{GB}{ }_{2}$ recorded the highest value of total chlorophylls ( $0.82 \mathrm{mg} / \mathrm{g} \mathrm{F} . \mathrm{W})$ compared to control $(0.72 \mathrm{mg} / \mathrm{g} \mathrm{F.W})$, whereas the least value was recorded in the plants irrigated with high level of salinity $\left(7 \mathrm{dSm}^{-1}\right)$ only $(0.53 \mathrm{mg} / \mathrm{g}$ F.W), while the highest value under the same salinity level was obtained with spraying with $\mathrm{Si}_{2}+\mathrm{GB}_{2}$ (0.69 mg/g F.W.).

\subsubsection{Total sugars}

There were significant increases in total sugars $\mathrm{mg} / \mathrm{g}$ F.W. with increased salinization levels in an ascending order (5.25, 6.52 and 6.96 $\mathrm{mg} / \mathrm{g}$ F.W.) with $\left(3.0,5.0\right.$ and $7.0 \mathrm{dSm}^{-1}$ salinity levels),respectively, compared to control $(4.67 \mathrm{mg} / \mathrm{g} \mathrm{F.W}$.) as indicated in Table (10).

As regard foliar application of $\mathrm{Si}$ and GB data illustrated that all treatments significantly increased total sugars mg/g F.W as compared to control. On the other hand, increasing concentration of both Si and/or GB significantly increased it. 


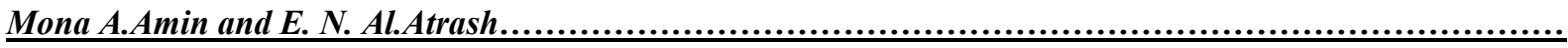

Table (10): Alleviation of salinity effectson Total chlorophylls ( $\mathrm{mg} / \mathrm{g} \mathrm{F.w.)}$, Total sugar ( $\mathrm{mg} / \mathrm{g} \mathrm{F.w.)and}$ Proline( $\mathrm{mg} / \mathrm{g}$ D.w) in shoots of Populus nigra by exogenous application of silicon and glycine betaine during $2019 / 2020$.

\begin{tabular}{|c|c|c|c|c|c|}
\hline \multirow{2}{*}{$\begin{array}{c}\text { Character } \\
\text { Salinity levels } \\
\text { Treatments }\end{array}$} & \multicolumn{5}{|c|}{$\begin{array}{c}\text { Total chlorophylls }(\mathrm{mg} / \mathrm{g} \mathrm{F} \text { F.w }) \\
\text { Salinity levels }\left(\mathrm{dSm}^{-1}\right)\end{array}$} \\
\hline & Control & $3 \mathrm{dSm}^{-1}$ & $5 \mathrm{dSm}^{-1}$ & $7 \mathrm{dSm}^{-1}$ & ***Mean \\
\hline Control & $0.72 \mathrm{k}$ & $0.60 \mathrm{p}$ & $0.55 q$ & $0.53 \mathrm{r}^{*}$ & $0.60 \mathrm{H}$ \\
\hline $\mathrm{Si}_{1}$ & $0.76 \mathrm{gh}$ & $0.73 \mathrm{jk}$ & 0.681 & $0.60 \mathrm{p}$ & $0.69 \mathrm{G}$ \\
\hline $\mathbf{S i}_{2}$ & $0.78 \mathrm{f}$ & $0.74 \mathrm{ij}$ & 0.691 & $0.63 \mathrm{o}$ & $0.71 \mathrm{~F}$ \\
\hline GB $_{1}$ & $0.79 \mathrm{ef}$ & $0.76 \mathrm{gh}$ & 0.681 & $0.65 n$ & $0.72 \mathrm{E}$ \\
\hline $\mathbf{G B}_{2}$ & $0.81 \mathrm{~cd}$ & $0.78 \mathrm{f}$ & $0.73 \mathrm{jk}$ & $0.671 \mathrm{~m}$ & $0.75 \mathrm{D}$ \\
\hline $\mathbf{S i}_{1+} \mathbf{G B}_{1}$ & $0.83 \mathrm{~b}$ & $0.78 \mathrm{f}$ & $0.75 \mathrm{hi}$ & $0.671 \mathrm{~m}$ & $0.76 \mathrm{C}$ \\
\hline $\mathrm{Si}_{1+} \mathrm{GB}_{2}$ & $0.85 \mathrm{a}$ & $0.80 \mathrm{de}$ & $0.77 \mathrm{fg}$ & 0.681 & $0.78 \mathrm{~B}$ \\
\hline $\mathbf{S i}_{2+} \mathbf{G B}_{1}$ & $0.81 \mathrm{~cd}$ & $0.79 \mathrm{ef}$ & $0.75 \mathrm{hi}$ & $0.66 \mathrm{mn}$ & $0.75 \mathrm{D}$ \\
\hline $\mathbf{S i}_{2+} \mathbf{G B}_{2}$ & $0.86 \mathrm{a}$ & $0.82 \mathrm{bc}$ & $0.79 \mathrm{ef}$ & 0.691 & $0.79 \mathrm{~A}$ \\
\hline \multirow[t]{2}{*}{ **Mean } & $0.80 \mathrm{~A}$ & $0.75 \mathrm{~B}$ & $0.71 \mathrm{C}$ & $0.64 \mathrm{D}$ & \\
\hline & \multicolumn{5}{|c|}{ Total sugars ( mg/g F.w) } \\
\hline Control & $3.40 \mathrm{r}$ & $4.00 \mathrm{p}$ & $5.50 \mathrm{i}-\mathrm{k}$ & $6.00 \mathrm{~h}$ & $4.73 \mathrm{H}$ \\
\hline $\mathrm{Si}_{1}$ & $3.80 \mathrm{q}$ & $4.50 \mathrm{no}$ & $5.9 \mathrm{oh}$ & $6.40 \mathrm{~g}$ & $5.15 \mathrm{G}$ \\
\hline $\mathrm{Si}_{2}$ & $4.10 \mathrm{p}$ & $4.70 \mathrm{n}$ & $6.20 \mathrm{~g}$ & $6.70 \mathrm{ef}$ & $5.42 \mathrm{~F}$ \\
\hline GB $_{1}$ & $4.40 \mathrm{o}$ & $4.90 \mathrm{~m}$ & $6.40 \mathrm{~g}$ & $6.90 \mathrm{de}$ & $5.65 \mathrm{E}$ \\
\hline $\mathbf{G B}_{2}$ & $4.70 \mathrm{n}$ & 5.201 & $6.70 \mathrm{ef}$ & 7.10b-d & $5.92 \mathrm{D}$ \\
\hline $\mathbf{S i}_{1+} \mathbf{G B}_{1}$ & 5.201 & $5.40 \mathrm{j}-1$ & $6.90 \mathrm{de}$ & $7.20 \mathrm{bc}$ & $6.17 \mathrm{C}$ \\
\hline $\mathrm{Si}_{1+} \mathbf{G B}_{2}$ & $5.50 \mathrm{i}-\mathrm{k}$ & $5.70 \mathrm{i}$ & $7.0 \mathrm{~cd}$ & $7.30 \mathrm{~b}$ & $6.37 \mathrm{C}$ \\
\hline $\mathbf{S i}_{2+} \mathbf{G B}_{1}$ & $5.30 \mathrm{kl}$ & $6.30 \mathrm{~g}$ & $6.90 \mathrm{de}$ & $7.20 \mathrm{bc}$ & $6.52 \mathrm{~B}$ \\
\hline $\mathrm{Si}_{2+} \mathbf{G B}_{2}$ & $5.60 \mathrm{ij}$ & $6.60 \mathrm{f}$ & $7.20 \mathrm{bc}$ & $7.90 \mathrm{a}$ & $6.82 \mathrm{~A}$ \\
\hline \multirow[t]{2}{*}{ Mean } & $4.67 \mathrm{D}$ & $5.25 \mathrm{C}$ & $6.52 \mathrm{~B}$ & $6.96 \mathrm{~A}$ & \\
\hline & \multicolumn{5}{|c|}{ Proline( mg/gD.w) } \\
\hline Control & $2.20 \mathrm{k}$ & $2.40 \mathrm{j}$ & $2.50 \mathrm{i}$ & $2.90 \mathrm{de}$ & $2.50 \mathrm{~F}$ \\
\hline $\mathrm{Si}_{1}$ & $2.40 \mathrm{j}$ & $2.70 \mathrm{~h}$ & $2.75 \mathrm{gh}$ & $3.20 \mathrm{c}$ & $2.76 \mathrm{E}$ \\
\hline $\mathrm{Si}_{2}$ & $2.44 \mathrm{ij}$ & $2.75 \mathrm{gh}$ & $2.80 \mathrm{fg}$ & $3.30 \mathrm{~b}$ & $2.82 \mathrm{D}$ \\
\hline GB $_{1}$ & $2.45 \mathrm{ij}$ & $2.77 \mathrm{f}-\mathrm{h}$ & $2.82 \mathrm{e}-\mathrm{g}$ & $3.30 \mathrm{~b}$ & $2.84 \mathrm{D}$ \\
\hline $\mathbf{G B}_{2}$ & $2.47 \mathrm{ij}$ & $2.79 \mathrm{fg}$ & $2.85 \mathrm{~d}-\mathrm{f}$ & $3.40 \mathrm{a}$ & $2.88 \mathrm{C}$ \\
\hline $\mathrm{Si}_{1+} \mathbf{G B}_{1}$ & $2.49 \mathrm{i}$ & $2.80 \mathrm{fg}$ & $2.89 \mathrm{de}$ & $3.44 \mathrm{a}$ & $2.91 \mathrm{BC}$ \\
\hline $\mathbf{S i}_{1+} \mathbf{G B}_{2}$ & $2.52 \mathrm{i}$ & $2.82 \mathrm{e}-\mathrm{g}$ & $2.90 \mathrm{de}$ & $3.47 \mathrm{a}$ & $2.93 \mathrm{~B}$ \\
\hline $\mathbf{S i}_{2+} \mathbf{G B}_{1}$ & $2.50 \mathrm{i}$ & $2.80 \mathrm{fg}$ & $2.89 \mathrm{de}$ & $3.42 \mathrm{a}$ & 2.90BC \\
\hline $\mathrm{Si}_{2+} \mathbf{G B}_{2}$ & $2.70 \mathrm{~h}$ & $2.84 \mathrm{~d}-\mathrm{f}$ & $2.92 \mathrm{~d}$ & $3.45 \mathrm{a}$ & $2.98 \mathrm{~A}$ \\
\hline Mean & $2.46 \mathrm{D}$ & $2.74 \mathrm{C}$ & $2.81 \mathrm{~B}$ & $3.32 \mathrm{~A}$ & \\
\hline
\end{tabular}

$\mathrm{Si}_{1}\left(\right.$ Silicon100mg/l), $\mathrm{S}_{2}$ (Silicon200mg/l), GB 1 (Glycinbetian 200mg/l), $\mathrm{GB}_{2}$ (Glycinbetian 400mg/l)

***Means values in the same column within each spraying substances followed by the same capital letters are not significant al level $5 \%$ probability.

**Means values in the same row within each irrigated with different levels of salinity followed by same capital letters are not significant at level of $5 \%$

* Mean values in the same row orcolumn within the interaction followed by the same small letter are not significant at $5 \%$. 
Also, data of the interaction between salinity level and foliar application of $\mathrm{Si}$ and/or GB, showed that the plants irrigated with the highest level of salinity $\left(7 \mathrm{dSm}^{-1}\right)$ and sprayed with $\mathrm{Si}_{2}+\mathrm{GB}_{2}$ increased significantly it (7.90 $\mathrm{mg} / \mathrm{g} \mathrm{F.W})$ compared to the control $(3.40 \mathrm{mg} / \mathrm{g}$ F.W), whereas the other spray treatments under the highest salinity level had no significant effect, irrespective to the obvious non significant results of the other salinity treatments.

\subsubsection{Proline content $(\mathrm{mg} / \mathrm{gD} . \mathrm{W})$}

As shown in Table (10), increasing salinization levels significantly increased proline content in an ascending order $(2.74,2.81$ and $3.32 \mathrm{mg} / \mathrm{g}$ D.W) with the $3.0,5.0$ and $7.0 \mathrm{dSm}^{-1}$ salinity levels, respectively, compared to the control (2.46 mg/gD.W).

The foliar application of $\mathrm{Si}$ and $\mathrm{GB}$ significantly increased the proline content as compared to control. Also, increasing the concentration of both $\mathrm{Si}$ and/or GB significantly increased it.

The interaction between salinity level and foliar application of $\mathrm{Si}$ and/or GB, showed that the highest level of salinity $\left(7 \mathrm{dSm}^{-1}\right)$ with $\mathrm{Si}_{1}+$ GB 2 significantly increased proline content (3.47 mg/gD.W) without significant differences between it and other foliar applications treatments.

These results could be ascribed to that biosynthesis of chlorophylls is generally inhibited by the depressive effect of salt stress on the absorption of some ions which are involved in the chloroplast formation, such as $\mathrm{Mg}, \mathrm{Fe}$ which could be expected as a reason for chlorophyll suppression in leaves and/ or an increase of growth inhibitors, such as ethylene or abscisic acid production which enhances senescence which occurred under stress conditions (El-Bagoury et al., 1999) on Casuarina equisetifolia L.. In fact, $\mathrm{Na}^{+}$ accumulation affects photosynthesis components such as enzymes, chlorophylls and carotonids (Davenport et al ., 2005). The highest content of total chlorophyll was obtained by spraying $\mathrm{Si}$ or GB either alone or in combination which may be due to improve photosynthesis activity, enhanced $\mathrm{K} / \mathrm{Na}$ selectively ratio, increased enzyme activity and increased concentration of soluble substances in the xylem.

The beneficial effects of $\mathrm{Si}$ on photosynthetic pigments have observed in Spartina densiflora (Mateos et al., 2013), which may be partly attributed to a $\mathrm{Si}$ mediated decrease in $\mathrm{Na}+$ uptake and increase in $\mathrm{K}+$ uptake and enhanced antioxidant defense, so it can be concluded that $\mathrm{Si}$ could alleviate the oxidative damage in plants under salt stress Yongxing and Haijun (2014). In this respect Ahmed et al. (2000) reported that the accumulation of non toxic substances such as sucrose, proline and organic acids are considered to be a protective adaptation and that the survival of plants under salinity conditions depends upon the regulation of metabolic processes and quantitive ratio between the protective and the toxic intermediates. Also, Yin et al. (2013) found that Si could significantly increase the level of sugar in sorghum under salt stress and could alleviate salt- induced osmotic stress. Proline is considered as a cytoplasm protective osmolyte necessary for adaptation to stress and the increased porline concentration could be a good parameter for salt tolerance plant (Ibrahim, 2008).

\subsection{4. $N, P$ and $K$.}

Data presented in Table (11) indicated that all salinization levels significantly decreased N,P and $\mathrm{K} \%$ in a descending order giving (3.60, 3.40 and 3.10 as for $\mathrm{N} \%),(0.38,0.35$ and 0 . 31 for $\mathrm{P} \%)$ and $(3.55,2.99$ and 2.51 for $\mathrm{K} \%)$ with treatment of $\left(3.0,5.0\right.$ and $\left.7.0 \mathrm{dSm}^{-1}\right)$, respectively, as compared tocontrol (3.94, 0.43 and $3.83 \%$ for N,P and $\mathrm{K}$ respectively.

As for foliar application of $\mathrm{Si}$ and $\mathrm{GB}$, the data illustrated that all treatments significantly increased $\mathrm{N}, \mathrm{P}$ and $\mathrm{K} \%$ as compared to control (neither salinized nor sprayed). On the other hand, increasing concentration of both $\mathrm{Si}$ and/or GB significantly increased N,P and $\mathrm{K} \%$ and $\mathrm{Si}_{2}+\mathrm{GB}_{2}$ recorded the highest effective value, whereas means of other treatments showed no significant difference between them.

Also, the data about the interaction between salinity level and foliar application of $\mathrm{Si}$ and/or GB, showed that the plants irrigated with the lowest level of salinity $\left(3 \mathrm{dSm}^{-1}\right)$ and sprayed with $\mathrm{Si}_{2}+\mathrm{GB}_{2}$ recorded the highest value of $\mathrm{N}, \mathrm{P}$ and $\mathrm{K} \%(3.78,0.46$ and $3.93 \%)$ compared to the control (neither salinized nor sprayed) which recorded $(3.60,0.32$ and $3.30 \%)$, whereas the lowest value of $\mathrm{N}, \mathrm{P}$ and $\mathrm{K} \%$ exhibited in the plants irrigated with high level of salinity (7 $\mathrm{dSm}^{-1}$ ) and did not receive any exogenous application (2.70, 0.28 and $2.00 \%)$ but the highest value under the same salinity level was on spraying with $\mathrm{Si}_{2}+\mathrm{GB}_{2}$ (3.34, 0.34 and 2.92 $\%)$. 


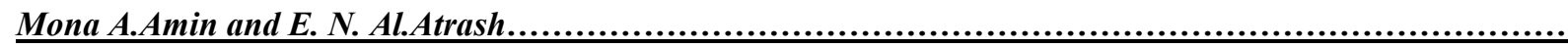

Table (11): Alleviation of salinity effects on $\mathrm{N}, \mathrm{P}$ and $\mathrm{K} \%$ in shoots of Populus nigra by exogenous application of silicon and glycine betaine during and2019/2020.

\begin{tabular}{|c|c|c|c|c|c|}
\hline \multirow{2}{*}{\begin{tabular}{c|} 
Character \\
Salinity levels \\
Treatment
\end{tabular}} & \multicolumn{5}{|c|}{$\begin{array}{c}(\mathrm{N} \%) \\
\text { Salinity levels }\left(\mathrm{dSm}^{-1}\right)\end{array}$} \\
\hline & Control & $3 \mathrm{dSm}^{-1}$ & $5 \mathrm{dSm}^{-1}$ & $7 \mathrm{dSm}^{-1}$ & ***Mean \\
\hline \begin{tabular}{|c|} 
Control \\
\end{tabular} & $3.60 \mathrm{gh}$ & $3.301-n$ & $3.10 \mathrm{pq}$ & $2.70 \mathrm{~s} *$ & $3.18 \mathrm{~F}$ \\
\hline $\mathbf{S i} \mathbf{i}_{1}$ & 3.80de & $3.40 \mathrm{j}-1$ & $3.20 \mathrm{n}-\mathrm{p}$ & $2.90 \mathrm{r}$ & $3.33 \mathrm{E}$ \\
\hline $\mathbf{S i} \mathbf{i}_{2}$ & $3.88 \mathrm{~cd}$ & $3.50 \mathrm{~h}-\mathrm{j}$ & 3.301-n & $3.00 \mathrm{qr}$ & $3.42 \mathrm{D}$ \\
\hline GB $_{1}$ & $3.92 \mathrm{bc}$ & $3.60 \mathrm{gh}$ & $3.40 \mathrm{j}-1$ & $3.10 \mathrm{pq}$ & $3.51 \mathrm{C}$ \\
\hline $\mathbf{G B}_{2}$ & $3.97 \mathrm{bc}$ & $3.62 \mathrm{fg}$ & $3.43 \mathrm{i}-\mathrm{k}$ & 3.17op & $3.55 \mathrm{C}$ \\
\hline $\mathbf{S i}_{1+} \mathbf{G B}_{1}$ & 4. $02 \mathrm{ab}$ & $3.72 \mathrm{ef}$ & $3.50 \mathrm{~h}-\mathrm{j}$ & $3.20 n-p$ & $3.61 \mathrm{~B}$ \\
\hline $\mathrm{Si}_{1} \mathbf{G B}_{2}$ & $4.12 \mathrm{a}$ & 3.78de & $3.57 \mathrm{gh}$ & $3.27 \mathrm{~m}-\mathrm{o}$ & $3.69 \mathrm{~A}$ \\
\hline $\mathbf{S i}_{2+} \mathbf{G B}_{1}$ & $4.08 \mathrm{a}$ & $3.72 \mathrm{ef}$ & $3.51 \mathrm{~g}-\mathrm{i}$ & 3.21 no & $3.63 \mathrm{~B}$ \\
\hline $\mathbf{S i}_{2+} \mathbf{G B}_{2}$ & $4.10 \mathrm{a}$ & 3.78de & $3.60 \mathrm{gh}$ & $3.34 \mathrm{k}-\mathrm{m}$ & $3.70 \mathrm{~A}$ \\
\hline \multirow[t]{2}{*}{ **Mean } & $3.94 \mathrm{~A}$ & $3.60 \mathrm{~B}$ & $3.40 \mathrm{C}$ & $3.10 \mathrm{D}$ & \\
\hline & \multicolumn{5}{|c|}{$(\mathrm{P} \%)$} \\
\hline Control & $0.32 \mathrm{kl}$ & $0.29 \mathrm{mn}$ & $0.28 \mathrm{no}$ & 0.280 & $0.29 \mathrm{G}$ \\
\hline $\mathbf{S i} \mathbf{i}_{1}$ & $0.33 \mathrm{~g}-\mathrm{j}$ & $0.32 \mathrm{kl}$ & $0.30 \mathrm{~m}$ & 0.280 & $0.31 \mathrm{~F}$ \\
\hline $\mathbf{S} \mathbf{i}_{2}$ & $0.34 \mathrm{gh}$ & $0.34 \mathrm{~g}-\mathrm{i}$ & 0.311 & $0.29 \mathrm{mn}$ & $0.32 \mathrm{E}$ \\
\hline GB $_{1}$ & $0.46 c$ & $0.35 \mathrm{fg}$ & $0.33 \mathrm{~h}-\mathrm{j}$ & $0.32 \mathrm{kl}$ & $0.36 \mathrm{D}$ \\
\hline $\mathbf{G B}_{2}$ & $0.47 \mathrm{~b}$ & $0.36 \mathrm{f}$ & $0.34 \mathrm{~g}-\mathrm{i}$ & $0.32 \mathrm{j}-1$ & $0.37 \mathrm{C}$ \\
\hline $\mathbf{S i}_{1+} \mathbf{G B}_{1}$ & $0.48 \mathrm{~b}$ & $0.45 \mathrm{c}$ & $0.38 \mathrm{e}$ & $0.33 \mathrm{i}-\mathrm{k}$ & $0.41 \mathrm{~B}$ \\
\hline $\mathrm{Si}_{1+} \mathbf{G B}_{2}$ & $0.48 b$ & $0.45 \mathrm{c}$ & 0.39de & $0.33 \mathrm{i}-\mathrm{k}$ & $0.41 \mathrm{~B}$ \\
\hline $\mathbf{S i}_{2+} \mathbf{G B}_{1}$ & $0.48 \mathrm{~b}$ & $0.45 \mathrm{c}$ & $0.38 \mathrm{e}$ & $0.33 \mathrm{i}-\mathrm{k}$ & $0.41 \mathrm{~B}$ \\
\hline $\mathbf{S i}_{2+} \mathbf{G B}_{2}$ & $0.49 \mathrm{a}$ & $0.46 \mathrm{c}$ & $0.39 \mathrm{~d}$ & $0.34 \mathrm{gh}$ & $0.42 \mathrm{~A}$ \\
\hline \multirow[t]{2}{*}{ **Mean } & $0.43 \mathrm{~A}$ & $0.38 \mathrm{~B}$ & $0.35 \mathrm{C}$ & $0.31 \mathrm{D}$ & \\
\hline & \multicolumn{5}{|c|}{$(\mathrm{K} \%)$} \\
\hline Control & $3.30 \mathrm{i}$ & $3.00 \mathrm{k}$ & $2.30 \mathrm{p}$ & $2.00 \mathrm{r}$ & $2.65 \mathrm{H}$ \\
\hline $\mathbf{S i} \mathbf{i}_{1}$ & $3.50 \mathrm{~h}$ & $3.20 \mathrm{j}$ & $2.50 \mathrm{o}$ & $2.20 \mathrm{q}$ & $2.85 \mathrm{G}$ \\
\hline $\mathbf{S i}_{2}$ & $3.60 \mathrm{~g}$ & $3.30 \mathrm{i}$ & $2.70 \mathrm{~m}$ & $2.30 p$ & $2.98 \mathrm{~F}$ \\
\hline GB $_{1}$ & $3.70 \mathrm{f}$ & $3.50 \mathrm{~h}$ & 2.901 & $2.50 \mathrm{o}$ & $3.15 \mathrm{E}$ \\
\hline GB $_{2}$ & $3.90 \mathrm{~cd}$ & $3.70 \mathrm{f}$ & $3.20 \mathrm{j}$ & $2.60 n$ & $3.35 \mathrm{D}$ \\
\hline $\mathbf{S i}_{1+} \mathbf{G B}_{1}$ & $3.98 b c$ & $3.74 \mathrm{ef}$ & $3.26 \mathrm{ij}$ & $2.67 \mathrm{mn}$ & $3.41 \mathrm{C}$ \\
\hline $\mathrm{Si}_{1+} \mathbf{G B}_{2}$ & $4.00 \mathrm{~b}$ & $3.82 \mathrm{de}$ & $3.32 \mathrm{i}$ & $2.70 \mathrm{~m}$ & $3.46 \mathrm{~B}$ \\
\hline $\mathbf{S i}_{2+} \mathbf{G B}_{1}$ & $3.92 \mathrm{bc}$ & $3.78 \mathrm{ef}$ & $3.29 \mathrm{i}$ & $2.70 \mathrm{~m}$ & $3.42 \mathrm{BC}$ \\
\hline $\mathrm{Si}_{2+} \mathbf{G B}_{2}$ & $4.60 \mathrm{a}$ & $3.93 \mathrm{bc}$ & $3.42 \mathrm{~h}$ & 2.921 & $3.72 \mathrm{~A}$ \\
\hline$* *$ Mean & $3.83 \mathrm{~A}$ & $3.55 \mathrm{~B}$ & $2.99 \mathrm{C}$ & $2.51 \mathrm{D}$ & \\
\hline
\end{tabular}

$\mathrm{Si}_{1}\left(\right.$ Silicon100mg/l), $\mathrm{S}_{2}($ Silicon200mg/l), GB 1 (Glycinbetian 200mg/l), GB 2 (Glycinbetian 400mg/l)

***Means values in the same column within each spraying substances followed by the same capital letters are not significant al level $5 \%$ probability.

**Means values in the same row within each irrigated with different levels of salinity followed by same capital letters are not significant at level of $5 \%$

*Mean values in the same row orcolumn within the interaction followed by the same small letter are not significant at $5 \%$.

\subsubsection{Na and $\mathrm{Cl} \%$}

The data in Table (12) indicated that there were significant increase in $\mathrm{Na}$ and $\mathrm{Cl} \%$ in a ascending order $(0.19,0.24$ and $0.29 \mathrm{Na} \%)$ and $(0.28,0.30$ and $0.35 \mathrm{Cl} \%)$ with the treatments of 3.0,5.0 and $7.0 \mathrm{dSm}^{-1}$ salinity level, respectively, compared to the control $(0.11 \mathrm{Na} \%$ and $0.16 \mathrm{Cl} \%$ ).

As for foliar application of $\mathrm{Si}$ and $\mathrm{GB}$ data illustrated that all treatments significantly decreased $\mathrm{Na}$ and $\mathrm{Cl} \%$ as compared to the Control (neither salinized nor sprayed). On the other hand, increasing concentration of both $\mathrm{Si}$ and/or GB significantly decreased $\mathrm{Na}$ and $\mathrm{Cl} \%$ and the lowest value obtained with $\mathrm{Si}_{2+} \mathrm{GB}_{2}$ wherease other combinations of $\mathrm{Si}$ and $\mathrm{GB}$ regard $\mathrm{Na} \%$ showed no significant difference between their effects, while as regard $\mathrm{Cl} \%$ other combinations of $\mathrm{Si}{ }_{1}+\mathrm{GB}_{1}$ and $\mathrm{Si}_{1}+\mathrm{GB}_{2}$ showed no significant difference between their effects. 
Table (12): Alleviation of salinity effects on $\mathrm{Na}$ and $\mathrm{Cl} \%$ in shoots of Populus nigra by exogenous application of silicon and glycine betaine during 2019/2020.

\begin{tabular}{|c|c|c|c|c|c|}
\hline \multirow{2}{*}{$\begin{array}{c}\text { Character } \\
\text { Salinity levels } \\
\text { Treatments }\end{array}$} & \multicolumn{5}{|c|}{$\begin{array}{c}\mathrm{Na} \% \\
\text { Salinity levels }\left(\mathrm{dSm}^{-1}\right) \\
\end{array}$} \\
\hline & Control & $3 \mathrm{dSm}^{-1}$ & $5 \mathrm{dSm}^{-1}$ & $7 \mathrm{dSm}^{-1}$ & $* * *$ Mean \\
\hline Control & $0.14 \mathrm{i}-\mathrm{k}$ & $0.33 c$ & $0.39 \mathrm{~b}$ & $0.54 \mathrm{a}^{*}$ & $0.35 \mathrm{~A}$ \\
\hline $\mathbf{S i}_{1}$ & $0.13 \mathrm{j}-1$ & $0.24 \mathrm{e}$ & $0.32 \mathrm{c}$ & $0.39 \mathrm{~b}$ & $0.27 \mathrm{~B}$ \\
\hline $\mathbf{S i}_{2}$ & $0.12 \mathrm{kl}$ & $0.22 \mathrm{f}$ & $0.28 \mathrm{~d}$ & $0.38 \mathrm{~b}$ & $0.25 \mathrm{C}$ \\
\hline GB $_{1}$ & $0.12 \mathrm{kl}$ & $0.19 \mathrm{~g}$ & $0.24 \mathrm{e}$ & $0.32 \mathrm{c}$ & $0.22 \mathrm{D}$ \\
\hline $\mathbf{G B}_{2}$ & $0.111 \mathrm{~m}$ & $0.15 \mathrm{hi}$ & $0.21 \mathrm{f}$ & $0.28 \mathrm{~d}$ & $0.19 \mathrm{E}$ \\
\hline $\mathbf{S i}_{1+} \mathbf{G B}_{1}$ & $0.111 \mathrm{~m}$ & $0.14 \mathrm{ij}$ & $0.23 \mathrm{ef}$ & $0.24 \mathrm{e}$ & $0.18 \mathrm{E}$ \\
\hline $\mathbf{S i}_{1+} \mathbf{G B}_{2}$ & $0.10 \mathrm{~m}$ & $0.14 \mathrm{i}-\mathrm{k}$ & $0.16 \mathrm{hi}$ & $0.17 \mathrm{~h}$ & $0.14 \mathrm{~F}$ \\
\hline $\mathbf{S i}_{2+} \mathbf{G B}_{1}$ & $0.10 \mathrm{~m}$ & $0.14 \mathrm{i}-\mathrm{k}$ & $0.15 \mathrm{hi}$ & $0.17 \mathrm{~h}$ & $0.14 \mathrm{~F}$ \\
\hline $\mathbf{S i}_{2+} \mathbf{G B}_{2}$ & $0.06 n$ & $0.13 \mathrm{j}-1$ & $0.14 \mathrm{i}-\mathrm{k}$ & $0.15 \mathrm{hi}$ & $0.12 \mathrm{G} \%$ \\
\hline \multirow[t]{2}{*}{ **Mean } & $0.11 \mathrm{D}$ & $0.19 \mathrm{C}$ & $0.24 \mathrm{~B}$ & $0.29 \mathrm{~A}$ & \\
\hline & \multicolumn{5}{|c|}{ Cl \% } \\
\hline Control & $0.261 \mathrm{~m}$ & $0.32 \mathrm{ef}$ & $0.42 \mathrm{c}$ & $0.56 \mathrm{a}$ & $0.39 \mathrm{~A}$ \\
\hline $\mathbf{S i}_{1}$ & $0.20 \mathrm{n}$ & $0.32 \mathrm{e}-\mathrm{g}$ & $0.34 \mathrm{e}$ & $0.46 \mathrm{~b}$ & $0.33 \mathrm{~B}$ \\
\hline $\mathrm{Si}_{2}$ & $0.16 \mathrm{qr}$ & $0.31 \mathrm{f}-\mathrm{h}$ & $0.33 \mathrm{e}$ & $0.38 \mathrm{~d}$ & $0.29 \mathrm{C}$ \\
\hline GB $_{1}$ & $0.14 \mathrm{rs}$ & $0.29 \mathrm{~h}-\mathrm{j}$ & $0.32 \mathrm{e}-\mathrm{g}$ & $0.33 \mathrm{e}$ & $0.27 \mathrm{D}$ \\
\hline $\mathbf{G B}_{2}$ & $0.13 \mathrm{st}$ & $0.29 \mathrm{i}-\mathrm{k}$ & $0.30-\mathrm{j}$ & $0.32 \mathrm{e}-\mathrm{g}$ & $0.26 \mathrm{E}$ \\
\hline $\mathrm{Si}_{1+} \mathbf{G B}_{1}$ & $0.13 \mathrm{st}$ & $0.28 \mathrm{jk}$ & $0.29 \mathrm{~h}-\mathrm{j}$ & $0.30 \mathrm{~g}-\mathrm{i}$ & $0.25 \mathrm{EF}$ \\
\hline $\mathrm{Si}_{1+} \mathrm{GB}_{2}$ & $0.13 \mathrm{st}$ & $0.27 \mathrm{kl}$ & $0.28 \mathrm{i}-\mathrm{k}$ & $0.30 \mathrm{~h}-\mathrm{j}$ & $0.25 \mathrm{~F}$ \\
\hline $\mathbf{S i}_{2+} \mathbf{G B}_{1}$ & $0.13 \mathrm{st}$ & $0.25 \mathrm{~m}$ & $0.25 \mathrm{~m}$ & $0.29 \mathrm{~h}-\mathrm{j}$ & $0.23 \mathrm{G}$ \\
\hline $\mathbf{S i}_{2+} \mathbf{G B}_{2}$ & $0.12 \mathrm{t}$ & $0.17 \mathrm{pq}$ & 0.19 no & 0.19 op & $0.17 \mathrm{H}$ \\
\hline$* *$ Mean & $0.16 \mathrm{D}$ & $0.28 \mathrm{C}$ & $0.30 \mathrm{~B}$ & $0.35 \mathrm{~A}$ & \\
\hline
\end{tabular}

$\mathrm{Si}_{1}\left(\right.$ Silicon100mg/l), $\mathrm{S}_{2}\left(\right.$ Silicon200mg/l), GB ${ }_{1}\left(\right.$ Glycinbetian 200mg/l), GB ${ }_{2}($ Glycinbetian 400mg/l)

***Means values in the same column within each spraying substances followed by the same capital letters are not significant al level $5 \%$ probability.

**Means values in the same row within each irrigated with different levels of salinity followed by same capital letters are not significant at level of $5 \%$

* Mean values in the same row orcolumn within the interaction followed by the same small letter are not significant at $5 \%$.

The interaction was found that irrigating with the lowest level of salinity $\left(3 \mathrm{dSm}^{-1}\right)$ with $\mathrm{Si}_{2}+\mathrm{GB}_{2}$ treatment recorded the lowest value of $\mathrm{Na}$ and $\mathrm{Cl} \%(0.13 \mathrm{Na}$ and $0.17 \mathrm{Cl} \%)$ compared to the control $(0.14 \mathrm{Na}$ and $0.26 \mathrm{Cl} \%)$, whereas the highest value of $\mathrm{Na}$ and $\mathrm{Cl} \%$ exhibited in the plants irrigated with high level of salinity (7 $\left.\mathrm{dSm}^{-1}\right)$ and did not receive any exogenous application $(0.54 \mathrm{Na} \%$ and $0.56 \mathrm{Cl} \%)$ but the lowest value under the same salinity level on spraying with $\mathrm{Si}_{2}+\mathrm{GB}_{2}$ was (0.15 Na and 0. 19 $\mathrm{Cl} \%$ ).

Generally, it can be mentioned that N,P and $\mathrm{K}$ concentrations decreased significantly corresponding to the increase in salinity levels, and this was with an agreement with Ahmed et al., 2000) who suggested that, salinity might be implicated indirectly in decreasing nitrogen concentration of plant due to the role played by chloride ions, and several detrimental effects of salinity stress on growth characters might be partially due to a decrease in nitrogen concentration. The reduction of $\mathrm{P} \%$ in plant by increasing salinity level might be explained as that $\mathrm{P}$ is vital element which is involved metabolic processes, but in salt stressed plants more metabolic activities and respiration processes are performed requiring more energy supply to be achieved consequent more $\mathrm{P}$ is consumed (Haniyat et al., 1992). In the same direction, K concentration in plants subjected to salinity stress exhibited a significant gradual decline by increasing salinity level, That may be due to the $\mathrm{Na}+$ ions that can substitute $\mathrm{K}+$ ions partially in plant tissue, hence the more concentrated salinity treatment, the more $\mathrm{Na}+$ substitution to consequently $\mathrm{K}+$ ions decrease in plant tissue. (Ashraf and O' leary, 1996). 
However there was a general tendency to increase $\mathrm{Na}$ and $\mathrm{Cl}$, with increasing salt concentration. It was found that accumulation of $\mathrm{Na}^{+}$and $\mathrm{Cl}^{-}$in the leaves caused damage of seedling which, at last, they died. This indicated that, the ability of some species tolerant to salinity seems to depend on its ability for chloride exclusion. Thus, it could be stated that, salinity appears to affect growth and plant tissue due to either toxic effects of $\mathrm{Na}+$ and/or $\mathrm{Cl}^{-}$ accumulation or to the high osmotic potential of the soil solution, (Wang and Han , 2007).

The exogenous application of $\mathrm{Si}$ or GB decreased the $\mathrm{Na}+$ and $\mathrm{Cl}^{-}$accumulation in the shoots, this was proposed to be the key mechanism of $\mathrm{Si}$ salt tolerance in plants (Liang and Ding, 2002 and Shi et al., 2013). So, it is noticeable worth that Populus nigra plants irrigated with low level of salinity( $3 \mathrm{dSm}-1)$ and sprayed with $\mathrm{Si}_{2}+\mathrm{GB}_{2}$ resulted in an increase in all growth parameters and improving the chemistry of the plants than those irrigated with control (neither salinized nor sprayed). At high salinity $\left(7 \mathrm{dSm}^{-1}\right)$ spraying the plants with $\mathrm{Si}_{2}+$ $\mathrm{GB}_{2}$ showed similar effects than those irrigated with saline water without any exogenous application. So, it can be concluded that spraying the Populus nigra plants with $\mathrm{Si}$ and/or GB counteracted the injurious effects resulting from salinity stress of irrigation.

\section{Conclusion}

It could be concluded that, high levels of salinity in irrigation water had a depressive effect on all parameters of growth, also had an effect on chemical composition of Populus nigra. On the other hand, these injuries due to salinity could be avoided by foliar application of silicon or glycine betaine individually or in combination as, they have an ameliorating effect on all morphological and physiological characters. Also, it prevented degradation of chlorophyll, enhanced accumulation of sugars and proline concentration, they improved $\mathrm{N}, \mathrm{P}$, $\mathrm{K}$ and decreased $\mathrm{Na}$ and $\mathrm{Cl}$ levels ,so the best growth was recorded with a mixture of Si 200 $\mathrm{mg} / \mathrm{l}$ and $\mathrm{GB} 400 \mathrm{mg} / \mathrm{l}$. Moreover, further researches are needed to investigate the effects of Si and GB foliar application on overcoming the harmful effects of salinity under field conditions, where the problem is more complex.

\section{REFERENCES.}

$\begin{array}{ccc}\begin{array}{c}\text { A.O.A.C. (1990). } \\ \text { Agriculture }\end{array} & \begin{array}{c}\text { Association of } \\ \text { Chemists. }\end{array} & \begin{array}{l}\text { Official } \\ \text { Official }\end{array}\end{array}$

Methods of Analysis, $15^{\text {th }}$ ed., Washington, D.C., U.S.A.

Agarie S., Agata W., Kubota F. and Kaufman P.B. (1992). Physiological roles of silicon in photosynthesis and dry matter production in rice plants. Japan. J. Crop Sci., 61:200-206.

Ahmed A.H., Mandour M.S., Ghallab A.M. and Diab J.A. (2000). Effect of nitrogen, potassium and foliar micronutrients fertilization on the the growth, yield and chemical composition of some sorghum cultivars growing under salin and sandy soil conditions. X Int'l Colloq. for the Optimization of Plant Nutrition. Plant Nutrition for the Next Millennuim Nut rients, Yield, Quality and the Enviroment. April 8-13, Cairo- Egypt.

Arteca R.N.(1996). Plant growth substances, principles and application. Chapman and Hall, New Yprk, USA.

Ashraf M. and Foolad M.R. (2007). Roles of glycine betaine and proline in improving plant abiotic stress resistance. Environ. Exp. Bot., 59: 206-216

Ashraf M. and O' leary J.W. (1996). Response of some newly developed salt-tolerant genotypes of spring wheat to salt stress: IYield components and ion distribution. J., Agron. Crop Sci., 176 (2): 91-101.

Bates L., Waldren S. and Teare I.D. (1973). Rapid determination of free proline for water-stress studied. Plant and Soil, 39: 205-207.

Black C.A. (1892). Methods of Soil Analysis. Part 2. American Society of Agronomy Agronomy. Inc, (Pub.), Madison, Wisconsin, USA.

Bockhaven V.J., Vleesschauwer D.E. and Höfte D. M. (2013). Towards establishing broad-spectrum disease resistance in plants: Silicon leads the way. J. Exp., Bot., 64:1281-1293.

Brown J.G. and Jackson R.K. (1955). Anote on the potentiometric determination of chloride. Proc. Amer. Soc. Hort. Sc., 65:187.

Chapman H.D. and Pratt P.P. (1961). Methods of Analysis for Soil, Plant and Water. Univ. Calif. Division of Agric. Sci., CA., USA.

Davenport R., James R., Zakrisson A., Plogander M., Tester M. and Munns R. (2005). Control of sodium transport in 
durum wheat. Plant Physiol., 137: 807818.

Dubois M., Smith F., Gilles K., Hammilton A. and Robers P.A. (1956). Colorimetric method to determination of sugars and related substances. Anal. Chem., 28 (3): 350-356.

Duncan D.B. (1955). Multiple rangeand Multiple F, test. Biometrics, 11:24.

Ehlting B., Dluzniewska P., Dietrich H., Selle A., Teuber M., Hänsch R., Nehls U., Polle A., Schnitzler J.P., Rennenberg H. and Gessler A. ( 2007). Interaction of nitrogen nutrition and salinity in grey poplar (Populus tremula $\times$ alba). Plant Cell Environ., 30: 796-811.

EL-Bagoury H.A., Hossni Y.A, El-Tantawy A. M., Shehata R. and Asmaael I. D. (1999). Effect of saline water irrigation on growth and chemical composition of Casuarina eguisetifolia L. seedlings. Egypt. J. Hort., 26: 47-57.

Epstein E. and Bloom A. J. (2005).In: Mineral Nutrition of Plants: Principles and Perspectives, $2^{\text {nd }}$ Edn.(Massachusetts): Sinaur Associates 400 P, ill., outhor and Subjected indexes. ISBN: 0-87893-172174. Sinauer, Sunderland (pub.).

Foyer C. and Spencer C. (1986). The relationship between phosphate status and photosynthesis in leaves. Effects on intracellular orthophosphate distribution, .photosynthesis and assimilate partitioning. Planta, 167(3) : 369-375.

Gong H. J., Chen K. M., Chen G. C., Wang S. M. and Zhang C. L. (2005). Silicon alleviates oxidative damage of wheat plants in pots under drought. Plant Sci., 169:313-321.

Gong H. J., Randall D. P. and Flowers T. J. (2006). Silicon Deposition in the root reduces sodium uptake in rice (Oryza sativa L.) seedlings by reducing bypass flow. Plant Cell Environ., 29: 1970-1979.

Haniyat M., El-Nimr K., Khalil M., Shafica N. and Nasr M. (1992). Growth, physiological and chemical composition of datura plants in saline soils. Egypt. J. Agric. Res., 70 (4): 997-1009.

Hashemi A., Abodolzadeh H. and Sadeghipour R. (2010).Beneficial effects of silicon nutrition in alleviating salinity stress in hydroponically grown canola, Brassica napus L. plants. Soil Sci. Plant Nutr., 56: $244-25$
Ibrahim I. S. (2008). Response of soybean roots to salinity and some mineral nutrients in vitro. J. Boil. Chem. Environ. Sci., 3 (4): $1-20$.

Jiang J., Huo Z. and Feng S. (2012). Effect of irrigation amount and water salinity on water consumption and water productivity of spring wheat in Northwest China. Field Crops Res., 137: 78-88.

Kanu M., Sidhu M., Champak K., and Purnendu B. (2017). Exogenous prolin and glycine betaine in plant under stress tolerance.Inr. j. Curr. Microbio.App.Sci.,6 (9): 901-913.

King E.J.(1951). Micro-Analysis in Medical Biochemistry. $2^{\text {nd }}$ Ed. Churchil.J. and A. churchhill, London, UK.

Letey J. and Feng G. L. (2007). Dynamic versus steady-state approaches to evaluate 26- irrigation management of salin water. Agric.Water Manag., 91:1.10.

Liang Y. H., Hua G,. Zhu J., Zhang C. and Cheng R. (2006). Importance of plant species and external silicon concentration to active silicon uptake and transport. New Phytol., 172: 63-72.

Liang Y.C. and Ding R.X. (2002). Influence of silicon on microdistribution of mineral ions in roots of salt-stressed barley as associated with salt tolerance in plants. Sci. China Ser. C., 45: 298-308.

Mateos E., Andrades M. and Davy A.J. (2013). Silicon alleviates deleterious effects of high salinity on the halaophytic grass Spartina densiflora. Plant Physiol. Biochem., 63:115-121.

Matoh T., Kairusmee P. and Takahashi E. (1986). Salt-induced damage to rice plants and alleviation effect of silicate. Soil Sci. Plant Nutr., 32: 295-304.

Mornai R.(1982).Formula for determination of chlorophyllus pigments extracted with N.N dimethyl fomamide.Plant Physiol.,69:1371-1381.

Nour-El Din A., Hegaz M., Abd-El -Gawad M. and Salem M.O.M. (1984). Effect of gibberellic acid application on som growth characters of wheat under wadi condition.Egypt.j.Agron.,91-2:17-28.

Parida A.K. and Das A.B.( 2004). Effects of $\mathrm{NaCl}$ stress on nitrogen and phosphorous metabolism in a true mangrove Bruguiera parviflora grown under hydroponic culture. J. of Plant Physiol., 161: 921-928. 
Piper G.S. (1947). Soil and Plant Analysis. Interscience (Pup.), Inc. New York. 368p.

Sakr M.T., El-Emery M.E. Fouda R.A. and Mowafy M.A. (2007). Role of some antioxidants in alleviating soil salinity stress. J. Agric. Sci. Mansoura Univ., 32: 9751-9763

Shi Y., Wang Y.C. Flowers T.J. and Gong H. J. (2013). Silicon decreases chloride transport in rice (Oryza sativa L.) in saline conditions. J Plant Physiol., 170:847-853.

Snedecor G. W. and Cochran G.W. (1980). Statistical Methods, $7^{\text {th }}$ ed. Iowa State University Press, (pub.) Ames, Iowa, USA.

Wang X.S .and Han J.G. (2007). Effects of $\mathrm{NaCl}$ and silicon on ion distribution in the roots, shoots and leaves of two alfalfa cultivars with different salt tolerance. Soil. Sci. Plant Nutr., 53:278-285.

Yer E.N., Baloglu M.C.and Ayan S. (2018). Identification and expression profiling of all family member genes under salinity stress in different poplar clones. Gene., 678: 324-336.

Yin L. N., Wang S.W. li J.Y. Tanaka K and Oka M. (2013). Application of silicon improves salt tolerance through ameliorating osmotic and ionic stresses in the seedling of Sorghum bicolor. Acta physiol. Plant. 35 (11), 3099-3107.

Yongxing Z. and Haijun G. (2014). Beneficial effects of silicon on salt and drought tolerance in plants. Agron.Sustain. Dev., 34:455-472.

Zhang H.L., Yao J. and Ma X.Y.( 2017). Populus euphratica J3 mediates root $\mathrm{K}^{+} / \mathrm{Na}^{+}$homeostasis by activating plasma membrane $\mathrm{H}^{+}$-ATPase in transgenic Arabidopsis under $\mathrm{NaCl}$ salinity . Plant Cell Tiss Organ Cult., 131:75-88.

Zhang H.L., Yao J. and Ma X.Y.( 2017). Populus euphratica J3 mediates root $\mathrm{K}^{+} / \mathrm{Na}^{+}$homeostasis by activating plasma membrane $\mathrm{H}^{+}$-ATPase in transgenic Arabidopsis under $\mathrm{NaCl}$ salinity . Plant Cell Tiss Organ Cult., 131:75-88.

Zhao K., Zhang X.M. Cheng Z.H. Yao W.J., Li R. H., Jiang T.B. and Zhou B.R. (2019). Comprehensive analysis of the three-amino-acid-loop-extension gene family and its tissue-differential expression in response to salt stress in poplar. Plant Physiol. Biochem.,136:. 112.

$$
\begin{aligned}
& \text { Populus nigra تحسين تأثير الملوحة على نمو شتتلات الحور الأسود } \\
& \text { بإستخدام الرش بالسيليكون والجلسين بيتايين } \\
& \text { منى أحمد أمين - عصام الدين نجيب الأطرش } \\
& \text { قسم بحوث الأشجار الخشبية ـ معهُ بحوث البساتين - مركز البحوث الزراعية ـ الجيزة }
\end{aligned}
$$

عرضت شتلات الحو الأسود Populus nigra إلى ثلاث مستو يات مختلفة من الملوحة $3.0,5.0$ and 7.0 dSm$^{-1}$

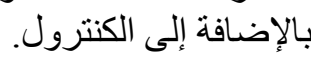

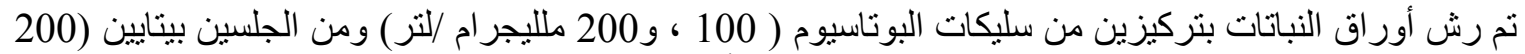

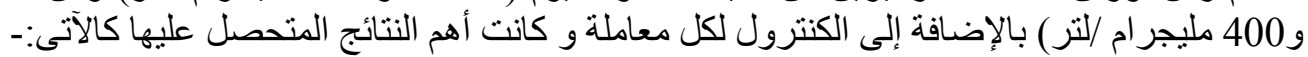

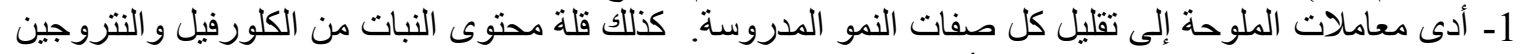

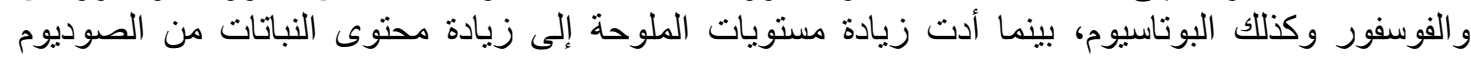
و الكلوريد و السكريات و البرولين.

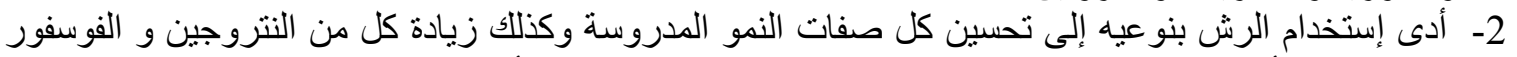

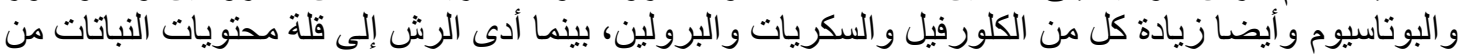
الصوديوم وكذلك الكلون الكوريد.

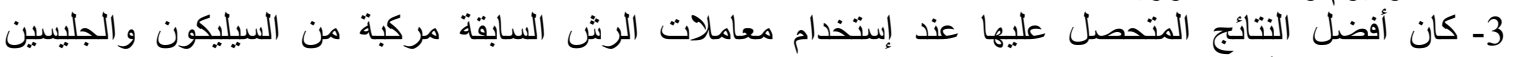

بالتركيزات الأعلى لكل منهما (200 مليجرام / لتر سليكات البوتاسيوم + 400 ملإيجرام /لتر جليسين بيتايين،

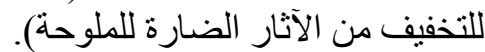

المجلة العلمية لكلية الزراعة - جامعة القاهرة ـ المجلد (71) العدد الرابع (أكتوبر 2020): 341- 356. 
Alleviation of the salinity effects on the growth and .................................................. 